\title{
Cancer-Type Expression of Tn Epitopes and LacdiNAc Structures: Human Cancer Cells Exhibit Distinctly Varying Levels of Heterogenous Ser/Thr Bearing Polypeptides, a Neutral $\beta$ Galactosidase Converting T-Hapten to Tn, Ser/Thr: $\alpha$ GalNAc- and GlcNAc: $\beta 1-3 /$ 11-4 GalNAc Transferase Activities
}

\author{
Chandrasekaran EV ${ }^{1 *}$, Xue J ${ }^{1}$, Piskorz $\mathrm{CF}^{1}$, Locke \\ $\mathbf{R D}^{1}$, Neelamegham $\mathrm{S}^{2}$ and Matta $\mathrm{KL}^{1,2 *}$ \\ ${ }^{1}$ Department of Cancer Biology, Roswell Park Cancer \\ Institute, Buffalo, NY, USA \\ ${ }^{2}$ Department of Chemical and Biological Engineering, \\ State University of New York, Buffalo, NY, USA \\ *Corresponding author: EV Chandrasekaran, \\ Department of Cancer Biology, Roswell Park Cancer \\ Institute, Buffalo, NY 14263, USA
}

Matta KL, Department of Cancer Biology, Roswell Park Cancer Institute, Buffalo, NY 14263, USA; Department of Chemical and Biological Engineering, State University of New York, Buffalo, NY 14260, USA

Received: August 09, 2021; Accepted: September 13, 2021; Published: September 20, 2021

\begin{abstract}
Terminal sugar-alteration in carbohydrate chains such as GalNAc replacing Gal in prostate and pancreatic cancers and Gal3-O-sulfation in breast, colon and gastric tumors could play a crucial role in cancer pathogenesis. We found the activities of cancer cell GalNAc transferases (GalNAc-Ts) as $0 \%$, $0 \%<20 \%, 20-50 \%$ and $20-120 \%$ respectively towards Gal $31-3 G a l N A c \alpha-O-$ Bn, 4-FGlcNAcß1-6 (Galß1-3)GalNAca-O-Bn, LacNAcß-O-Bn, GlcNAcß1-4 GlcNAc $\beta-O-B n$ and GlcNAc $\beta 1-6 G a l N A c \alpha-O-B n$ as compared to GlcNAc $\beta-O-$ $\mathrm{Bn} . \alpha-\left[6-{ }^{3} \mathrm{H}\right] \mathrm{GalNAc}-\mathrm{ylated}$ endogenous cancer cells Ser/Thr polypeptides by the corresponding cancer cell aGalNAc-T were at variable levels, heterogenous, and exhibited complete binding to VVL-agarose and non-binding to WGA-, WFL- and ConA- agarose. PNA-agarose binding and non-binding radioactive products from $\left[{ }^{-}{ }^{3} \mathrm{H}\right]$ GalNAc-ylated exogenous acceptor GlcNAcß1-6(Galß1-3) GalNAca-O-Al indicated cancer type variable $\beta 1-3 G$ alactosidase activities at neutral $\mathrm{pH}$. TLC analysis identified two radioactive products by confirming PNA-agarose data. WGA-agarose tight binding and VVL-agarose weak binding respectively of the products $\left[6-{ }^{3} \mathrm{H}\right]$ GalNAc $\beta 1-4$ and $\beta 1-3 \mathrm{GlcNAc} \beta-\mathrm{O}-$ $\mathrm{Bn}$ isolated from the exogenous acceptor GIcNAc- $\beta-\mathrm{O}-\mathrm{Bn}$ by Sep-Pak $\mathrm{C} 18$ method were used to quantitate $\beta 1-4$ and $\beta 1-3 \mathrm{GalNAc}-\mathrm{T}$ activities in cancer cells. DU4475, MDA-MB-435S, PA-1, LNCaP, PC3, DU145, EG7 and GL261OVA over-expressed $\beta 1$-3GalNAc-T activity. Tumorigenic MDA-MB-435/LLC6 as compared to non-tumorigenic MDA-MB-435S contained $\sim 2$-fold each of aGalNAc-T and $\beta 1-4$ GalNAc-T. The breast cancer DU4475 uniquely expressed 10-fold $\beta 1-3 G$ alNAc-T with respect to $\beta 1-4$ GalNAc-T. HPLC identified negligible $\beta 1-6$ GalNAc-T in cancer cells and high-level $\beta 1-3$ GalNAc- $T$ in pancreatic and gastric tumors. It is known that $\mathrm{Tn}$ epitopes correlate with cancer progression and metastasis and $\beta$-galactosidase is a senescence-biomarker and moleculartarget for ovarian cancer. It is apparent that $\beta$ GalNAc-T, Tn polypeptides, $\alpha$ GalNAc-T and neutral $\beta 1-3$ galactosidase could play a crucial role in cancer pathogenesis.
\end{abstract}

Keywords: Cancer cell O-glycans; Tn polypeptides; T-hydrolyzing neutral $\beta 1-3$ galactosidase; $\alpha$ GalNAc- and $\beta 1-3 / 1-4$ GalNAc transferases; Lectinagarose; HPLC and TLC

\section{Abbreviations}

AL: Allyl; Bn: Benzyl; BSA: Bovine Serum Albumin; ConA: Concavalin A; GalNAc-T: GalNAc Transferase; HPLC: High Performance Lipid Chromatography; NEU: Sialidase; PNA: Peanut Agglutinin; RM: Reaction Mixture; SA- $\beta$ Gal: SenescenceAssociated $\beta$ Galactosidase; ST: Sialyltransferase; TLC: Thin Layer Chromatography; Tn GalNAca-O-Ser/Thr: T Gal $\beta 1-3$ GalNAca-OSer/Thr Type-I LDN GalNAc $\beta 1-3$ GlcNAc (LacdiNAc) Type-II LDN GalNAc $\beta 1-4 G l c N A c$ (LacdiNAc); VVL: Vicia Villosa Lectin; WFL:
Wisteria Floribunda Lectin; WGA: Wheat Germ Agglutinin

\section{Introduction}

The glycoproteins containing complex glycan structures serve as the communication interface between cells and intracellular environment [1]. Several studies indicate that glycans and glycosylation of cellular proteins participate in the process of cancer cell adhesion, dissemination, and metastasis [2-5]. An unique expression of fucosyltransferase FT VI by colon cancer cell lines was
Austin J Cancer Clin Res - Volume 8 Issue 3 - 2021 ISSN : 2381-909X | www.austinpublishing group.com Chandrasekaran et al. (C) All rights are reserved
Citation: Chandrasekaran EV, Xue J, Piskorz CF, Locke RD, Neelamegham S and Matta KL. Cancer-Type Expression of Tn Epitopes and LacdiNAc Structures: Human Cancer Cells Exhibit Distinctly Varying Levels of Heterogenous Ser/Thr Bearing Polypeptides, a Neutral $\beta$ Galactosidase Converting T-Hapten to Tn, Ser/Thr: aGalNAc- and GlcNAc: $\beta 1-3 / \beta 1-4$ GalNAc Transferase Activities. Austin J Cancer Clin Res. 2021; 8(3): 1097. 
identified by using GlcNAc $\beta 1-4$ GlcNAc as the specific acceptor [6]. The pattern of glycosyl- and glycan: Sulfotransferase activities in a wide range of human cancer cell lines was shown to be able to predict individual cancer associated signature carbohydrate structures [7]. A significant role for glycosyltransferases in invasion and intractability of pancreatic cancer became evident from a high-level overexpression of glycosyltransferases in pancreatic tumor [8]. Distinct changes in glycosyltransferases- specificities and lectin-binding by replacing terminal Gal with GalNAc in carbohydrate chains indicated that terminal sugar alteration could play a major role in cancer pathogenesis [8].

The LacdiNAc group is found mainly in N-glycans but also occurs in O-glycans [9-11]. The expression of the LacdiNAc group in $\mathrm{N}$-glycans was reported to vary in human breast, prostate, ovarian and pancreatic cancers [12]. LacdiNAc-glycosylated PSA was better than the conventional PSA in identifying patients with clinically significant prostate cancer [13]. The NeuAca2-6 GalNAc $\beta 1-4 \mathrm{GlcNAc}$ sequence specifically found in secretory glycoproteins [14]. Recently mammalian glycoproteins were shown to carry GalNAc $\beta 1-3 \mathrm{GlcNAc}$ on $\mathrm{N}$-glycans in contrast to the presence of GalNAc $\beta 1-4 \mathrm{GlcNAc}$ structures in $\mathrm{N}$ - and $\mathrm{O}$ - glycans of many mammalian glycoproteins, suggesting that GalNAc $\beta 1-3$ GlcNAc and GalNAc $\beta 1-4 G l c N A c$ terminal units in glycans may have different roles in vivo [15].

The O-glycans impart unique features to mucin glycoproteins [16-19]. The first committed step in O-glycan biosynthesis is the addition of GalNAc to Ser/Thr [20]. Some aGalNAc-transferases such as T2 and T4 accomplish high-density glycosylation of certain protein substrates probably through binding as lectins [21]. Unsubstituted Tn epitopes occur in human cancers of colon, breast, bladder, prostate, liver, ovary and stomach and their presence correlate with cancer progression and metastases [22-24]. The expression of aGalNAc glycoconjugates detected by binding of HPA was found to be associated with metastatic competence and poor prognosis in a range of human adenocarcinomas [25]. ST6GalNAc1 mediated sialylation of Tn antigen and the frequent mutation of the cosmc chaperone that is required for the galactosyltransferase activity results in incomplete glycan structures [26].

The present study examined the acceptors-specificities of GalNAc transferases by using a variety of chemically synthesized compounds and identified by lectin-agarose affinity chromatography the levels of GlcNAc: $\beta 1-3$ and $\beta 1-4$ GlaNAc tranferase activities in several human cancer cell lines. We found in these cell lines distinctly different levels of Tn epitope generating Ser/Thr containing small polypeptides (2-6 KD) and aGalNAc transferase activities. The present study found significant levels of a $\beta$ galactosidase capable of converting $\mathrm{T}$-glycotope to $\mathrm{Tn}$ at neutral $\mathrm{pH}$ in human cancer cell lines.

\section{Materials and Methods}

\section{Cancer cell lines}

T47D, MDA-MB-231, MCF-7, ZR-75-1, DU4475, MDA-MB435S, MDA-435/LCC6 (breast), COLO 205, SW1116, LS180 (colon), SW626, PA-1 (ovarian), HL60 (leukemic), Hep G2 (hepatic), LNCaP, PC3, DU145 (prostate), U87GB (glioblastoma), EG7 (lymphoma), RIF (fibrosarcoma) and GL261-OVA (glioma) were cultured as recommended by ATCC (Manassas, VA) and as reported in earlier studies $[6,7,27]$. All cell samples were homogenized with $0.1 \mathrm{M}$ TrisMaleate pH 7.2 containing 2\% Triton X-100 using a Dounce glass, hand-operated homogenizer. The homogenate was centrifuged at $16,000 \mathrm{~g}$ for $1 \mathrm{~h}$ at $4^{\circ} \mathrm{C}$. Protein was measured on the supernatants by the BCA micro method (Pierce Chemical Co) with BSA as the standard. The supernatants were adjusted to $5 \mathrm{mg}$ protein $/ \mathrm{mL}$ by adding the necessary amount of extraction buffer and then stored frozen at $-20^{\circ} \mathrm{C}$ until use.

\section{Tissue specimens}

The tissue specimens were obtained from the tissue procurement facility of Roswell Park Cancer Institute. All tissue specimens were stored frozen at $-70^{\circ} \mathrm{C}$ until processed as reported earlier $[6,7,28,29)$. The tissue samples were homogenized at $4^{\circ} \mathrm{C}$ with 4 volumes $(1 \mathrm{ml} /$ per g tissue) of 0.1M Tris-Maleate pH 7.2 using Kinematica. After adjusting the concentration of Triton-X100 to $2 \%$, these homogenates were mixed in the cold room for $1 \mathrm{~h}$ using Speci-Mix (Thermolyne) and then centrifuged at $20,000 \mathrm{~g}$ for $1 \mathrm{~h}$ at $4^{\circ} \mathrm{C}$. The clear fat free supernatant was adjusted to $10 \mathrm{mg} / \mathrm{ml}$ protein by adding $0.1 \mathrm{M}$ TrisMaleate pH 7.2 containing $2 \%$ TritonX100 and stored frozen at $-20^{\circ} \mathrm{C}$ until use.

\section{Acceptor compounds}

The chemically synthesized compounds have already been used as acceptors for glycosyltransferases in our earlier studies and thus are well documented acceptor compounds for the study of glycosyltransferases [8,30-32].

\section{Column chromatography}

Biogel-P2 column or Biogel-P6 column (Fine Mesh; 1.0x116.0 cm) chromatography was carried out with $0.1 \mathrm{M}$ pyridine acetate ( $\mathrm{pH}$.4) as the eluent at room temperature. Void volume of this column is $30 \mathrm{~mL}$. The peak fraction containing $\left[6-{ }^{3} \mathrm{H}\right]$ GalNAc radioactivity were pooled, lyophilized to dryness, dissolved in a small volume of water and stored frozen at $-20^{\circ} \mathrm{C}$ for further experimentation. Lectin-agarose affinity chromatography was carried out using columns of $7 \mathrm{ml}$ bed volume of ConA-, PNA-, WGA-, WFL- and VVL- agarose (Vector Lab, Burlingame, CA) under conditions recommended by supplier $[6,32]$. The radioactive sample was applied to the column in $1.0 \mathrm{ml}$ of the running buffer. After entry of the sample into the column bed, the sample remained in contact with the gel for $20 \mathrm{~min}$ before starting elution with the running buffer. Fractions of $1 \mathrm{ml}$ were collected. The bound material from WGA-agarose was eluted with $0.5 \mathrm{M}$ GlcNAc and from WFL-agarose and VVL-agarose were eluted with 1.0M Gal. PNA-agarose and ConA agarose bound materials were eluted with $0.2 \mathrm{M} \mathrm{Gal}$ and $0.1 \mathrm{M}$ methyla-D-mannoside respectively. Depending on the time of elution, the lectin binding interactions of WGA, VVL and WFL were classified into four categories; non-binding, weak binding, regular binding and tight binding as explained in our earlier

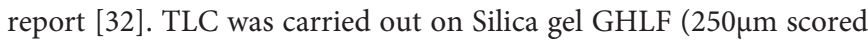
$20 \mathrm{X} 20 \mathrm{~cm}$; Analtech Newark DE). The solvent system 1-propanol/ $\mathrm{NH} 4 \mathrm{OH} / \mathrm{H} 2 \mathrm{O}(12 / 2 / 5 \mathrm{v} / \mathrm{v})$ was used [31]. The [6- $\left.{ }^{3} \mathrm{H}\right]$ GalNAc products were located by scraping $0.5 \mathrm{~cm}$ width segments of silica gel and soaking in $2.0 \mathrm{ml}$ water in vials followed by liquid scintillation counting. Pronase digestion of Biogel P-2 $\left[6-{ }^{3} \mathrm{H}\right]$ GalNAc containing peak 1 fraction was carried out in $600 \mu \mathrm{l}$ reaction mixture containing $4 \mathrm{mg}$ pronase $\mathrm{CB}, 0.1 \mathrm{M}$ Tris. HCL pH 7.0, $2 \mathrm{mM} \mathrm{CaCl}_{2}$ and $2 \%$ ethanol at $37^{\circ} \mathrm{C}$ for $18 \mathrm{~h}$ and then subjected to Biogel P- 6 chromatography. 
Table 1A: Specificity of plant lectins PNA, VVL and WGA utilized in the present study as detailed in this table A. PNA- and VVL binding specificity as revealed by Hapten inhibition using enzyme linked lectin assay [33]

\begin{tabular}{|c|c|c|c|c|}
\hline & \multicolumn{2}{|c|}{ PNA } & \multicolumn{2}{|c|}{ VVL } \\
\hline & $\mathrm{mM}$ & $\mathrm{I}(\%)$ & $\mathrm{mM}$ & $I(\%)$ \\
\hline Galß1-3GalNAca-O-AI & 0.23 & 50 & 4 & 12 \\
\hline Galß1-3 (6-O-Me) GalNAca-O-Al & 0.18 & 50 & 2 & 0 \\
\hline Galß1-3(6-O-Sulfo) GalNAca-O-AI & 0.71 & 50 & 2 & 0 \\
\hline Galß1-3 (NeuAca2-6) GalNAca-O-Bn & 1.75 & 50 & 2 & 0 \\
\hline 3-O-Sulfo Galß1-3GalNAca-O-Al & 4 & 4 & 4 & 5 \\
\hline 6-O-Sulfo Galß1-3GaINAca-O-AI & 2 & 7 & 2 & 0 \\
\hline NeuAc Galß1-3GalNAca-O-Bn & 2 & 0 & 2 & 0 \\
\hline GalNAca-O-Al & 4 & 9 & 1 & 50 \\
\hline 6-O-Sulfo GalNAca-O-ONP & 2 & 10 & 2 & 6 \\
\hline NeuAca2-6GalNAca-O-Bn & $\mu \mathrm{M}$ & & $\mu \mathrm{M}$ & \\
\hline Galß1-3GalNAca-O-Al/acrylamide copolymer & 0.05 & 50 & 8.3 & 0 \\
\hline GalNAca-O-Al/acrylamide copolymer & 8.3 & 6 & 0.02 & 50 \\
\hline Antifreeze glycoprotein & 1.9 & 50 & 19.6 & 13 \\
\hline
\end{tabular}

Note: The lectin binding data presented in A from our earlier studies in order to achieve a meaningful understanding of the results obtained in the present study.

Table 1B: Specificity of plant lectins PNA, VVL and WGA utilized in the present study as detailed in this table B.

WGA- and PNA- agarose binding characteristics revealed by affinity chromatography [32]

\begin{tabular}{|c|c|c|}
\hline \multicolumn{3}{|c|}{ WGA- and PNA- agarose binding characteristics revealed by affinity chromatography [32] } \\
\hline \multicolumn{3}{|c|}{ WGA-agarose } \\
\hline 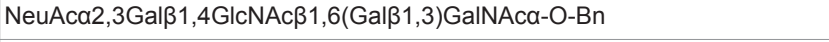 & \multicolumn{2}{|c|}{ NB } \\
\hline Galß1,4(Fuca1,3)GlcNAcß-O-Bn & \multicolumn{2}{|c|}{ NB } \\
\hline GalNAc $\beta 1,3($ Fuca1,4)GlcNAc $\beta-O-B n$ & \multicolumn{2}{|c|}{ NB } \\
\hline NeuAca2,6GalNAc $\beta 1,4$ GlcNAc $\beta-O-B n$ & \multicolumn{2}{|c|}{ NB } \\
\hline 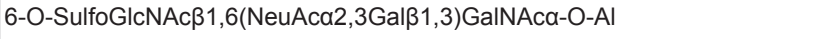 & \multicolumn{2}{|c|}{ RB } \\
\hline 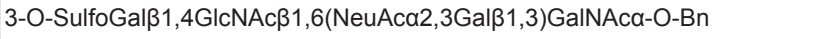 & \multicolumn{2}{|c|}{ RB } \\
\hline 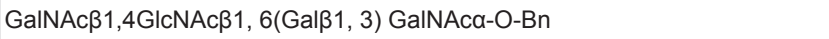 & \multicolumn{2}{|c|}{ TB } \\
\hline GalNAc $\beta 1,4($ Fuca1,3)GlcNAc $\beta-O-B n$ & \multicolumn{2}{|c|}{ TB } \\
\hline 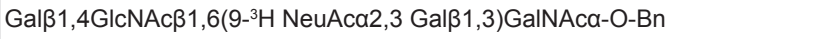 & \multicolumn{2}{|c|}{ TB } \\
\hline \multicolumn{3}{|c|}{ PNA-agarose } \\
\hline Gala1,3Galß1,4GIcNAcß1,6(3-O-MeGalß1,3)GalNAca-O-Bn & \multicolumn{2}{|c|}{ NB } \\
\hline 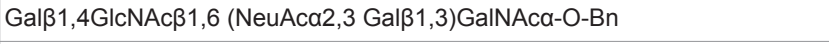 & \multicolumn{2}{|c|}{ NB } \\
\hline 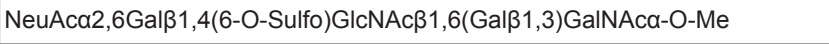 & \multicolumn{2}{|c|}{ NB } \\
\hline Gala1,3Gal $\beta 1,4$ GlcNAc $\beta 1,6($ Gal $\beta 1,3)$ GalNAca-O-Bn & \multicolumn{2}{|c|}{ RB } \\
\hline \multirow[t]{2}{*}{ Galß1,4(Fuca1,3)GlcNAcß1,6(Galß1,3)GalNAca-O-Bn } & \multicolumn{2}{|c|}{ RB } \\
\hline & WGA-agarose & VVL-agarose \\
\hline GalNAc $\beta 1-3 G \mid c N A c \beta-O-B n$ & NB & WB \\
\hline GalNAc $\beta 1-4 G \mid c N A c \beta-O-B n$ & TB & RB \\
\hline
\end{tabular}

Note: The lectin binding data presented in B from our earlier studies in order to achieve a meaningful understanding of the results obtained in the present study. NB: Non-Binding; RB: Regular Binding; TB: Tight Binding.

$\left[6-{ }^{3} \mathrm{H}\right]$ labelling of GaINAc $\beta 1-3 \mathrm{GICNAc} \beta-\mathrm{O}-\mathrm{Bn}$, GaINAc $\beta 1$ $4 \mathrm{GIcNAc} \beta-\mathrm{O}-\mathrm{Bn}$ and GaINAc $\beta 1-6 \mathrm{GICNAc} \beta-\mathrm{O}-\mathrm{Bn}$

These synthetic compounds $(1.5 \mu \mathrm{mol})$ were mixed separately with $20 \mathrm{U}$ of galactose oxidase and $200 \mathrm{U}$ of horse radish peroxidase in $0.1 \mathrm{M}$
Na-phosphate buffer $\mathrm{pH} 7$ in $160 \mu \mathrm{l}$ reaction volume and incubated at $37^{\circ} \mathrm{C}$ for $21 \mathrm{~h}$ and the oxidized GalNAc product was isolated by SepPak method. The methanol eluates ( $5 \mathrm{ml}$ each) were concentrated to dryness and dissolved in $200 \mu \mathrm{l}$ of $0.05 \mathrm{M} \mathrm{Na-phosphate} \mathrm{buffer} \mathrm{pH} 7$, 
and then mixed with $100 \mu \mathrm{l} \mathrm{NaB}\left[{ }^{3} \mathrm{H}\right] 4(5 \mathrm{mCi} / 500 \mu \mathrm{l}$ of $0.05 \mathrm{M} \mathrm{Na}-$ phosphate $\mathrm{pH} 7.0$ ) and left at room temperature for $2 \mathrm{~h}$. Then $100 \mu \mathrm{l}$ $\mathrm{NaBH} 4(100 \mathrm{mg} / \mathrm{ml}$ water) was added, mixed well intermittently, and left at room temp for $1 \mathrm{~h}$. Then these three solutions were neutralized by adding drops of acetic acid, left in the cold room overnight and the $\left[6-{ }^{3} \mathrm{H}\right]$ labelled compounds were isolated by Sep-Pak method.

\section{Assay of GalNAc Transferases [8]}

The incubation mixture $(1.6 \mathrm{ml})$ contained $0.1 \mathrm{M}$ Hepes $\mathrm{pH} 7.0$ containing protease inhibitors (Calbiochem), exogenous synthetic acceptor Gal $\beta 1,3$ (GlcNAc $\beta 1,6)$ GalNAc-o-Allyl $(3.0 \mu \mathrm{mol}), 20 \mathrm{mM}$ $\mathrm{Mn}$ acetate, $7 \mathrm{mM}$ ATP, $3 \mathrm{mM}$ Na azide, UDP-GalNAc (Sigma Chemical Co. St. Louis, MO; $0.2 \mu \mathrm{mol})$, UDP- $\left(6-{ }^{3} \mathrm{H}\right)$ GalNAc

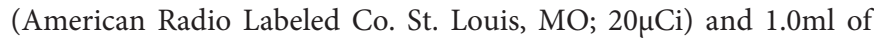
Triton X100 solubilized cell extract. The final concentration of UDPGalNAc and the exogenous acceptor were $0.125 \mathrm{mM}$ and $1.9 \mathrm{mM}$ respectively. After incubation at $37^{\circ} \mathrm{C}$ for $20 \mathrm{~h}$, the incubation mixture was fractionated on a Biogel P2 column for the separation and quantitation of the radioactive products arising from endogenous and exogenous accetors. For the isolation of $\left[6-{ }^{3} \mathrm{H}\right]$ GalNAc-yl product from GlcNAc $\beta-\mathrm{O}-\mathrm{Bn}, 200 \mu \mathrm{l}$ of the incubation mixture contained $0.6 \mu \mathrm{m}$ of GlcNAc $\beta-\mathrm{O}-\mathrm{Bn}$ and $100 \mu$ lof cell or tissue extract and other components in the same proportion as above. The radioactive products from benzylglycosides were separated by hydrophobic chromatography on a Sep-Pak C18 cartridge (Waters, Milford, $\mathrm{MA}$ ) and elution of the product was done with $3 \mathrm{~mL}$ methanol. The methanol eluate was concentrated to dryness by flash evaporation, dissolved in a small volume of water and stored frozen at $-20^{\circ} \mathrm{C}$ for experimentation.

\section{HPLC}

The HPLC separation [31] was performed on a C18 reverse-phase column using a gradient of acetonitrile in $10 \mathrm{mM}$ ammonium formate ( $\mathrm{pH} 4.0$ ). The sample injection volume was $20 \mu \mathrm{l}$.

\section{Results}

\section{Lectin specificities}

The present study utilized the specificities of PNA, VVL and WGA for characterizing $\mathrm{N}$-acetyl galactosaminyl products from the endogenous and exogenous acceptors. Table 1 explains the specificities of these lectins using hapten inhibition assay showed that Gal 1 1-3GalNAca-O-Al and its acrylamide copolymer are the most effective compounds for PNA. Antifreeze glycoprotein containing Gal $\beta 1-3$ GalNAca-O-Ser/Thr chains was also highly effective. Any substitution on Gal in Gal $\beta 1$-3GalNAca- abolishes the inhibitory activity. The hapten inhibition of PNA binding is reduced considerably by methyl, sulfate or NeuAc substituent on $\mathrm{C}_{6}-\mathrm{OH}$ whereas they almost abolished the VVL binding. GalNAca-O-Al and its acrylamide copolymer are effective in inhibiting VVL binding. Lectin agarose chromatography indicates NeuAca2-3Gal $\beta 1-3$ (GlcNAc $\beta 1-6)$ GalNAC $\alpha$ is the unit for regular binding of WGA whereas GalNAc $\beta 1-4 \mathrm{GlcNAc}$ unit as such imparts tight binding to WGA. PNA-binding is inhibited by NeuAc and sulfate group on the $\beta 1-6$ linked chain in mucin core 2 structure but not by aGal or Fuc.

\section{Characterization of $\left[{ }^{6}-{ }^{3} \mathrm{H}\right]$ GalNAc containing product from endogenous acceptor}

When Gal $\beta 1-3$ (GlcNAc $\beta 1-6)$ GalNAca-O-Al was incubated with LNCaP cell extract and subjected to Biogel P2 column chromatography, the $\left[6-{ }^{3} \mathrm{H}\right]$ GalNAc-yl product from this acceptor emerge as Peak II fraction whereas the $\left[6-{ }^{3} \mathrm{H}\right]$ GalNAc-yl product from endogenous acceptor emerge first designated as Peak I fraction (Figure 1A). When 4-Fluoro GlcNAc $\beta 1-6$ (Gal $\beta 1-3)$ GalNAca$\mathrm{O}-\mathrm{Bn}$ ) was subjected to the same treatment, there was only Peak I radioactive product (Figure 1B) indicating that there was no transfer of $\left[6^{-}{ }^{3} \mathrm{H}\right]$ GalNAc to 4 -FluoroGlcNAc as anticipated. When Peak I and Peak II fractions were treated with $\beta \mathrm{N}$-acetyl hexosaminidase (Jack bean) and then subjected to Biogel P2 chromatography, Peak I fraction was not affected (Figure 1C) whereas Peak II was hydrolyzed for a complete release of $\left[6-{ }^{3} \mathrm{H}\right]$ GalNAc (Figure 1D). Further, Peak I radioactive material did not bind at all to ConA- agarose (Figure 1E), WGA-agarose (Figure 1F) and also mostly to WFL-agarose (Figure 1G), but bound completely to VVL- agarose (Figure 1H) indicating its identity as Tn epitope bearing Ser/Thr polypeptides. When Peak I radioactive material was subjected to Biogel P6 column chromatography before and after Pronase digestion, the conversion of endogenous a GalNAc-ylated polypeptides to aGalNAc containing small peptides was evident as shown in (Figure 1I).

\section{Characterization of $\left[6-{ }^{3} \mathrm{H}\right]$ GalNAc containing product from exogenous acceptor Galß1-3(GIcNAc $\beta 1-6)$ GalNAca-O-AI}

It is evident that $\left[6-{ }^{3} \mathrm{H}\right]$ GalNAc is transferred to $\beta 1-6$ linked GlcNAc in $\beta$ linkage since it is completely released by Jack bean $\beta$ $\mathrm{N}$-Acetyl hexosaminidase digestion (Figure 1D) and GalNAc is transferred likely to C-4 hydroxyl group of GlcNAc since 4 Fluoro GlcNAc containing acceptor is inactive (Figure 1B). The synthetic $\left[6-{ }^{3} \mathrm{H}\right]$ GalNAc compounds namely $\left[6-{ }^{3} \mathrm{H}\right]$ GalNAc $\beta 1-3$ and $\beta$ 1-4 GlcNAC- $\beta-\mathrm{O}-\mathrm{Bn}$ showed respectively non-binding (Figure $1 \mathrm{~J}$ ) and tight binding to WGA-agarose (Figure $1 \mathrm{~K}$ ) whereas they exhibited respectively weak binding (Figure $1 \mathrm{~L}$ ) and regular binding (Figure $1 \mathrm{M})$ to VVL-agarose and both radioactive compounds showed complete regular binding to WFL-agarose (data not shown). The [6$\left.{ }^{3} \mathrm{H}\right]$ GalNAc-yl product from Gal $\beta 1-3$ (GlcNAc $\beta 1-6$ ) GalNAca-O-Al (Biogel P2 Peak II fraction) surprisingly showed only $73 \%$ binding to PNA-agarose (Figure $1 \mathrm{~N}$ ). It showed $80 \%$ binding to WGAagarose (Figure 1O) indicating that the binding product contains $\beta$ 1-4 linked GalNAc. It is interesting to note that complete binding of this radioactive product (Biogel P2 Peak II fraction) was seen with WFL-agarose (Figure 1P) which binds GalNAc linked $\beta 1-3$ as well as $\beta$ 1-4 to GlcNAc whereas $\alpha$ GalNAc containing polypeptides (Biogel P2 Peak I fraction) did not bind to WFL-agarose (Figure $1 G$ ). It shows further that Biogel P2 Peak II fraction is not contaminated by a GalNAc containing polypeptides.

\section{Carbohydrate specificities of $\beta$ GalNAc-transferase activities in cancer}

As reported in Table 2, we used chemically synthesized compounds as acceptors and the Triton-X100 solubilized extract of 2 different cancer cells T47D (breast) and LS180 (colon) as enzyme source. Gal $\beta$ 1 -3GalNAc $\alpha$-O-Bn and D-Fuc $\beta$ 1-3GalNAc $\alpha$-O-Bn, 3-O-MeGal $\beta$ 1-4GlcNAc $\beta$ 1-6 (Gal $\beta$ 1-3)GalNAc- $\alpha-O-B n$ and 4-F GlcNAc $\beta 1-6$ (Gal $\beta 1-3$ )GalNAca-O-Bn did not serve as acceptors for GalNAc-T of T47D and LS180 indicating that non-transfer of GalNAC to T-hapten and also to 4-F GlcNAc whereas Gal $\beta$ 1-3GlcNAc $\beta-\mathrm{O}-\mathrm{Bn}, \mathrm{Gal} \beta$ 1-4GlcNAc $\beta$-O-Bn and Gal $\beta$ 1-4GlcNAc $\beta$ 1-6 (3-O-MeGal $\beta 1-3$ ) GalNAc served as acceptors to some extent indicating the possibility 


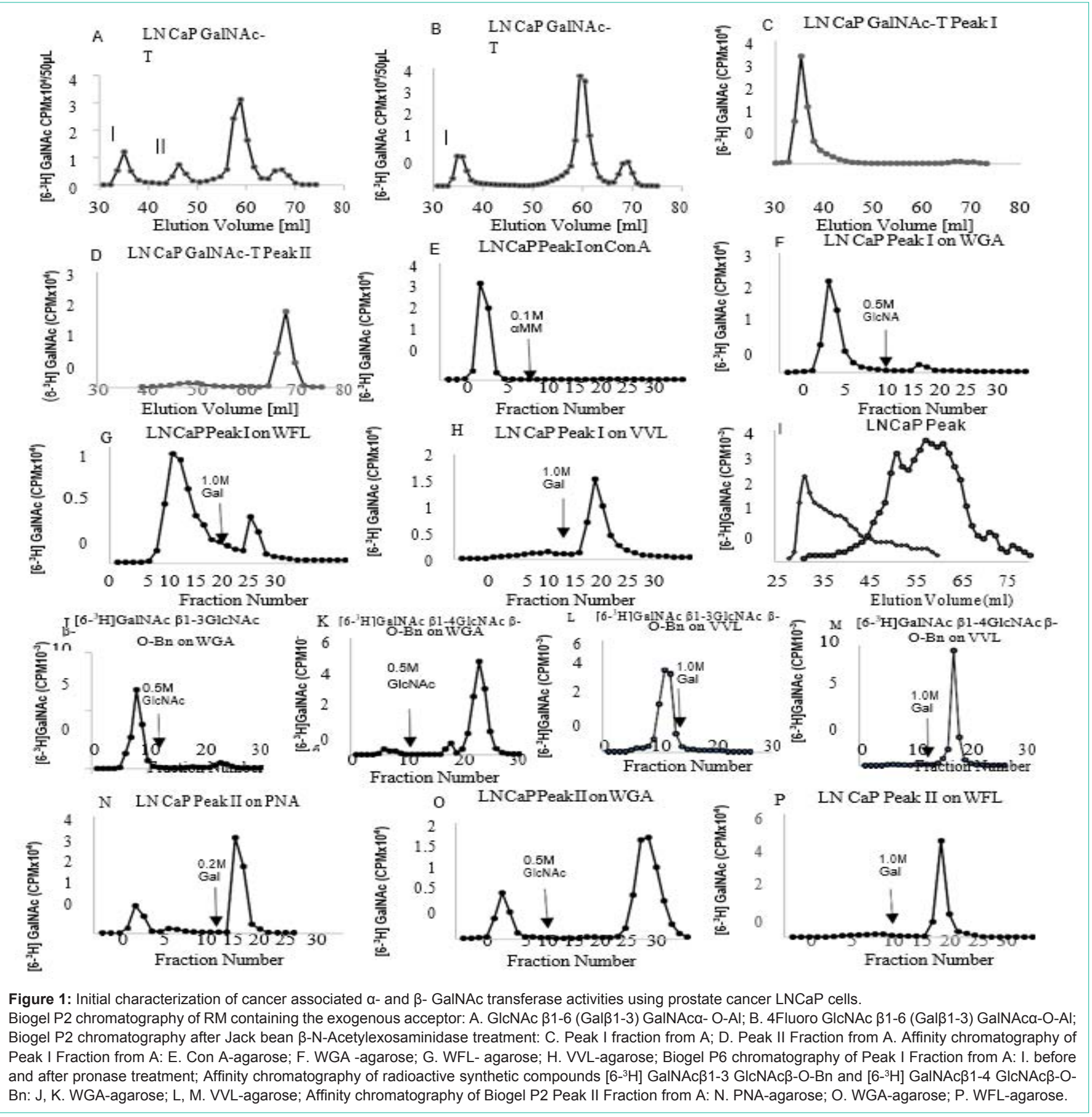

of minor extension of LacNAc chain by GalNAc. The other acceptors containing the GlcNAc terminal namely Gal $\beta$ 1-3/D- Fuc $\beta$ 1-3/Fuc $\alpha 1-2 \mathrm{Gal} \beta$ 1-3 (GlcNAc $\beta$ 1-6) GalNAca-O-Bn acted as acceptors for GalNAc T. GlcNAc B-O-Bn was the best acceptor in both cases indicating that both $\beta$ 1-3 and $\beta$ 1-4 GalNAc transferases can use this acceptor since this acceptor contains no other sugar residues for exerting specificity related constraints.

\section{Cancer cell $\beta$ GalNAc transferase activities towards three synthetic acceptors}

All cancer cells (Table 3) showed less activity towards GlcNAc linked $\beta 1-4$ to GlcNAc $\beta$-O-Bn as compared to GlcNAc $\beta$-O-Bn in the range of 21.1-38.9\% (breast cancer), 37.0-49.2\% (colon cancer), 33.341.2\% (ovarian cancer), 33.3\% (leukemia), 25.9\% (hepatic cancer) and $30.2-37.2 \%$ (prostate cancer). As GlcNAc $\beta 1-4$ GlcNAc $\beta-O-B n$ may serve as an acceptor favorable to $\beta 1-3 \mathrm{GalNAc}$ transfer, these values would suggest a higher level of $\beta 1$ - 4GalNAc transferase activity as compared to $\beta 1-3 \mathrm{GalNAc}$ transferase activity in cancer cells. GlcNAc $\beta-\mathrm{O}-\mathrm{Bn}$ would act as a favorable acceptor for both $\beta 1-3$ and $\beta 1-4$ GalNAc transferases whereas GlcNAc $\beta 1-6$ GalNAca-O-Bn would be a more favorable acceptor for $\beta 1-4$ GalNAc transferase as suggested by the inactivity of 4-FGlcNAc $\beta 1-6$ (Gal $\beta 1-3)$ GalNAc 
Table 2: Specificities of $\beta$ GalNAc transferase activities present in two different cancer cells as revealed by chemically synthesized compounds tested as acceptors. Incorporation of $\left[6-{ }^{3} \mathrm{H}\right]$ GalNAc $\left(\mathrm{CPM} \times 10^{-4}\right)$ into the acceptors catalyzed by $1 \mathrm{mg}$ protein of solubilized

\begin{tabular}{|c|c|c|}
\hline \multirow{2}{*}{ Synthetic Compounds } & \multicolumn{2}{|c|}{ cell extract } \\
\hline & T47D (Breast cancer) & LS180 (Colon cancer) \\
\hline GlcNAc $\beta-O-B n$ & 10.6 & 3.4 \\
\hline Galß1-3GalNAca-OBn & 0 & 0 \\
\hline D-Fuc $\beta 1-3 G a l N A c \alpha-O B n$ & 0 & 0 \\
\hline D-Fuc $\beta 1-3$ (GlcNAc $\beta 1-6$ ) GalNAca-OBn & 3.5 & 2.1 \\
\hline Galß1-3 (GlcNAc $\beta 1-6)$ GalNAca-OBn & 3.9 & 2.1 \\
\hline Galß1-4GlcNAc $\beta-O-B n$ & 1.2 & 0.6 \\
\hline Galß1-3GlcNAcß-O-Bn & 2.1 & 0.1 \\
\hline Fuca1-2 Galß1-3 (GlcNAc $\beta 1-6$ ) GalNAca-OBn & 4.3 & 2.5 \\
\hline 4-FGlcNAcß1-6 (Galß1-3) GalNAca-O-Bn & 0 & 0.1 \\
\hline 3-O-MeGalß1-3 (GlcNAcß1-6) GalNAca-O-Bn & 3.7 & 2.3 \\
\hline $\begin{array}{l}\text { 3-O-MeGalß1-4 GlcNAcß1-6 (Galß1-3) GalNAca- } \\
\text { O-Bn }\end{array}$ & 0 & 0 \\
\hline
\end{tabular}

Table 3: Human cancer cell line GalNAc T activities as measured with three synthetic acceptors namely GlcNAC $\beta-O-B n$, GlcNAc $\beta 1-6 G a l N A c \alpha-O-B n$ and GIcNAc $\beta 1-4 G I c N A c \beta-O-B n$.

\begin{tabular}{|c|c|c|c|}
\hline \multirow{2}{*}{ Cancer Cells } & \multicolumn{3}{|c|}{ Incorporation of $\left[6-{ }^{-3} \mathrm{H}\right] \mathrm{GlaNAc}\left(\mathrm{CPM} \times 10^{-4}\right)$ into the acceptor catalyzed by $1 \mathrm{mg}$ protein of solubilized cell extract } \\
\hline & GIcNAC $\beta-O-B n$ & GIcNAc $\beta 1-6$ GaINAc $\alpha-O-B n$ & GIcNAc $\beta 1-4 G I c N A c \beta-O-B n$ \\
\hline \multicolumn{4}{|l|}{ Breast Cancer } \\
\hline T47D & 4.28 & $3.88(90.7)$ & $1.54(36.0)$ \\
\hline MDA-MB-231 & 3.22 & $3.20(99.4)$ & $0.88(27.4)$ \\
\hline MCF-7 & 2.9 & $2.54(87.5)$ & $1.13(38.9)$ \\
\hline ZR-75-1 & 12.06 & $7.35(61.0)$ & $3.02(25.0)$ \\
\hline DU4475 & 9.5 & $2.28(24.0)$ & $2.05(21.6)$ \\
\hline MDA-MB-435S & 1.1 & $0.62(56.4)$ & $0.23(21.1)$ \\
\hline MDA-435/LCC6 & 1.54 & $1.23(79.6)$ & $0.57(37.1)$ \\
\hline \multicolumn{4}{|l|}{ Colon Cancer } \\
\hline COLO205 & 2.82 & $3.11(110.4)$ & $1.39(49.2)$ \\
\hline SW1116 & 2.65 & $2.55(96.4)$ & $1.01(38.1)$ \\
\hline LS180 & 3.43 & $2.38(69.4)$ & $1.27(37.0)$ \\
\hline \multicolumn{4}{|l|}{ Ovarian Cancer } \\
\hline SW626 & 3.94 & $3.10(78.8)$ & $1.62(41.2)$ \\
\hline PA-1 & 1.72 & $1.14(66.5)$ & $0.57(33.3)$ \\
\hline \multicolumn{4}{|l|}{ Leukemia } \\
\hline HL60 & 4.02 & $2.74(68.3)$ & $1.34(33.3)$ \\
\hline \multicolumn{4}{|l|}{ Hepatic Cancer } \\
\hline HepG2 & 7.14 & $7.03(98.5)$ & $1.85(25.9)$ \\
\hline \multicolumn{4}{|l|}{ Prostate Cancer } \\
\hline LNCaP & 4.52 & $5.27(116.6)$ & $1.68(37.2)$ \\
\hline PC3 & 3.68 & $2.84(77.2)$ & $1.21(32.9)$ \\
\hline DU145 & 7.56 & $5.86(77.5)$ & $2.28(30.2)$ \\
\hline \multicolumn{4}{|l|}{ Miscellaneous } \\
\hline U87GB (Glioblastoma) & 5.44 & ND & ND \\
\hline EG7 (Lymphoma) & 2.22 & ND & ND \\
\hline RIF (Fibrosarcoma) & 5.6 & ND & ND \\
\hline GL261-OVA (Glioma) & 3.64 & ND & ND \\
\hline
\end{tabular}

Note: ND: Not Determined Values in parenthesis are the activities towards the two acceptors GlcNAc $\beta 1-6 G a l N A c \alpha-O-B n$, GIcNAc $\beta 1-4 G I c N A c \beta-O-B n$ in percentage with respect to the activity towards GIcNAc $\beta-\mathrm{O}-\mathrm{Bn}$. 


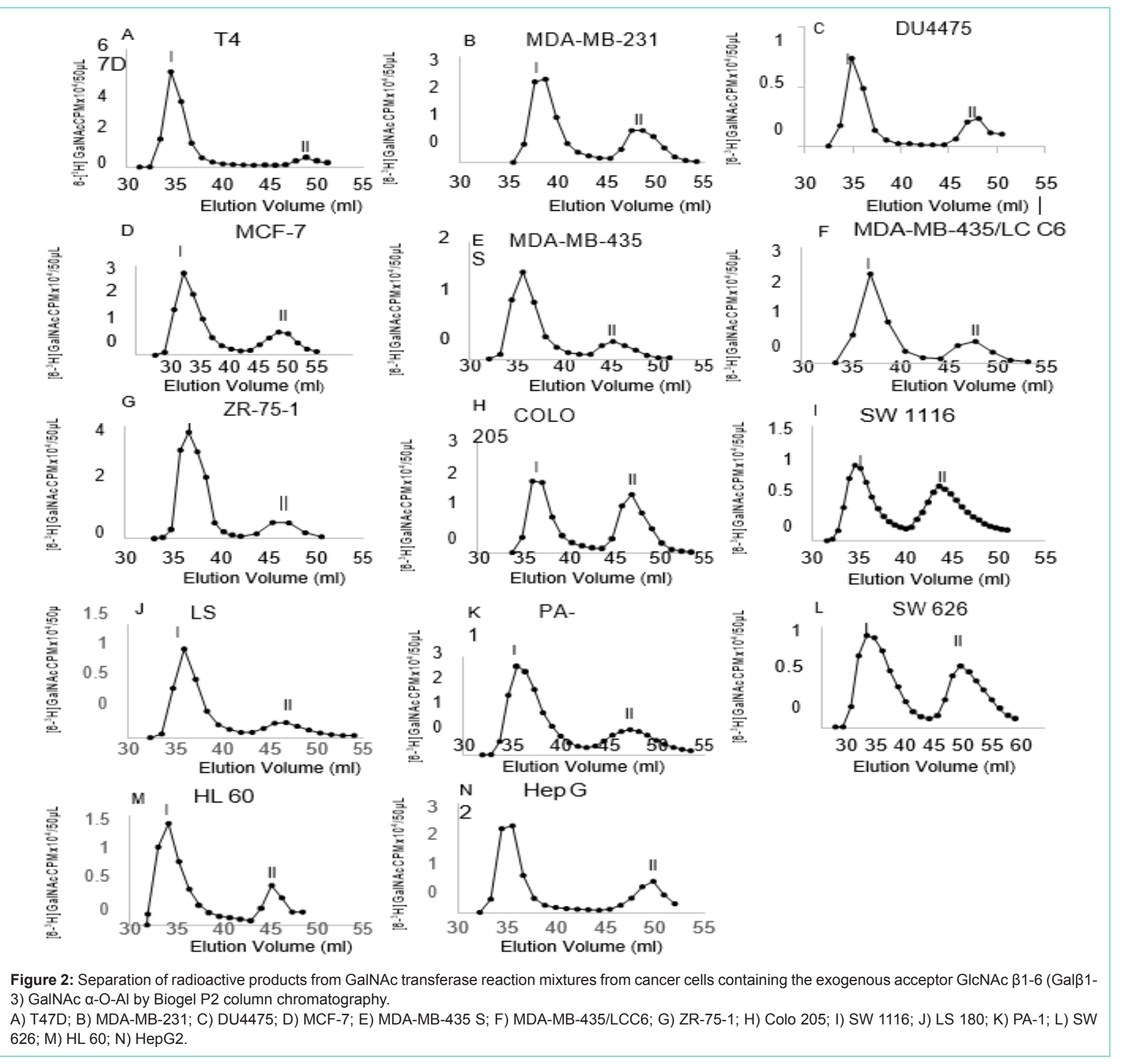

$\alpha-\mathrm{O}-\mathrm{Bn}$ as an acceptor. The activity towards GlcNAc $\beta 1-6$ GalNAca$\mathrm{O}-\mathrm{Bn}$ as compared to GlcNAc $\beta-\mathrm{O}-\mathrm{Bn}$ is slightly less in most cases except for considerably lower values in ZR-75-1 (61.0\%), DU4475 (24.0\%) and MDA-MB-435S (56.4\%) and slightly higher values in Colo205 (110.4\%) and LNCaP (116.6\%). The exceptionally low level of GalNAc transferase activity towards $\beta$ 1-6 linked GlcNAc exhibited by DU4475 appears to be an unique situation that would possibly indicating the predominance of $\beta 1$-3GalNAc transferase activity in DU4475.

The levels of $\left[6-{ }^{3} \mathrm{H}\right]$ GalNAc-yl products from endogenous Ser/Thr containing polypeptides and exogenous acceptor namely mucin core 2 trisaccharide Gal $\beta 1-3$ (GIcNAc $\beta 1-6$ ) GaINAc $\alpha-O-A l$ from various cell lines

The chemically synthesized compound GlcNAc $\beta 1-6$ (Gal $\beta 1-3$ )
GalNAca-O-Al was used as the exogenous acceptor for GlcNAc: $\beta$ GalNAc-transferases. The purity of this compound was established by its mobility as a single spot in TLC (located on the TLC plates by spraying with sulfuric acid in ethanol and heating at $100 \mathrm{o}$ C) using two different solvent systems 1-propanol/NH4OH/H2O (12/2/5, $\mathrm{V} / \mathrm{V})$ and $\mathrm{CHCL} 3 / \mathrm{CH} 3 \mathrm{OH} / \mathrm{H} 2 \mathrm{O}(5 / 4 / 1, \mathrm{~V} / \mathrm{V})$. Further after $\left[9-{ }^{3} \mathrm{H}\right]$ sialylation with cloned ST3 Gal II, this compound moved as a single radioactive compound on TLC in the above two solvent systems, being located by scrapping $0.5 \mathrm{~cm}$ width segments of silica gel and soaking them in $2 \mathrm{ml}$ water in vials followed by liquid scintillation counting. Mass spectral analysis confirmed the identity and purity of these non-sialylated and sialylated compounds [31].

Figure 2 presents the Biogel P2 column chromatographic profiles of $\left[6^{-}{ }^{3} \mathrm{H}\right]$ GalNAc-yl products (Peak I and Peak II) by the action of 


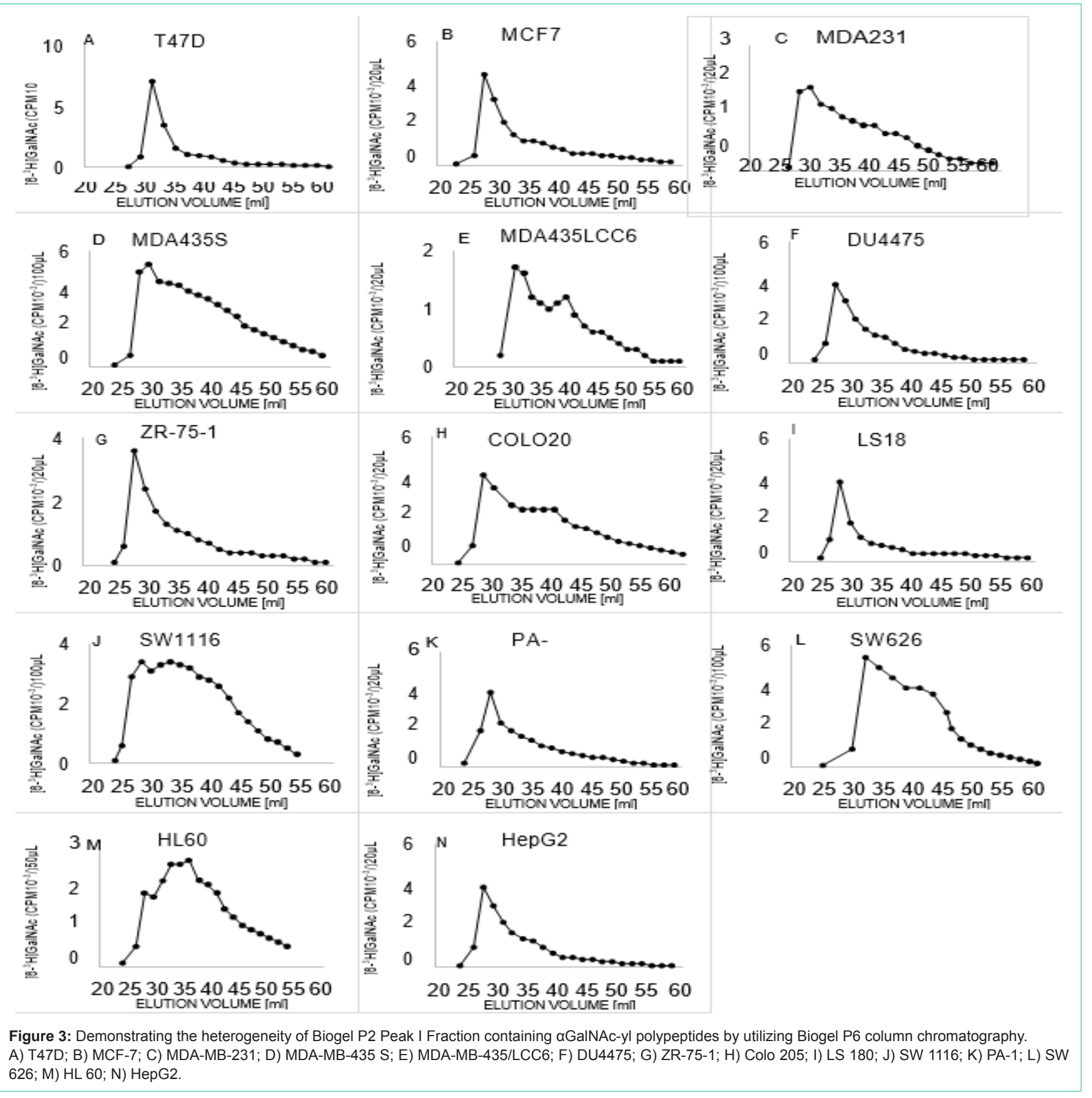

GalNAc-transferases present in TritonX-100 solubilized extracts from various cancer cell lines.

When Peak I endogenous $\left[6-{ }^{3} \mathrm{H}\right]$ GalNAc-yl products from the various cell lines were examined by Biogel P6 column chromatography (Figure 3), it was evident that they contained quite heterogenous Tn epitope bearing small poly peptides. Tn polypeptides from T47D, MCF-7, DU4475, ZR75-1, LS180, PA-I and HepG2 (Figure $3 \mathrm{~A}, 3 \mathrm{~B}, 3 \mathrm{~F}, 3 \mathrm{G}, 3 \mathrm{I}, 3 \mathrm{~K}$ and $3 \mathrm{~N}$ respectively) are comparatively larger than those from remaining cell lines (Figure 3C,3D,3E,3H,3J,3L and $3 \mathrm{M}$ respectively). We have already demonstrated that $\left[6-{ }^{3} \mathrm{H}\right]$ GalNAc-yl endogenous material (Biogel P2 Peak I) can be digested to smaller Tn peptide fragments by pronase digestion (refer Biogel P6 chromatography Figure 1I).

In all cases (Table 4) except for LS180 and LNCaP, the level of endogenous product exceeded the product from exogenous acceptor. It is quite remarkable that all breast cancer cell lines exhibited a high level of Tn containing polypeptides in the range of 1.9 - 8.8-fold that of corresponding exogenous product. SW116, PA1, HL60 and HepG2 also showed a high level of Tn polypeptides 3.9, 2.2, 3.5 and 2.5- fold respectively. Further, it is noteworthy that $\beta$ GalNAc- transferase activity towards GlcNAc in Gal $\beta-3($ GlcNAc $\beta-6)$ GalNAca-O-Al was found in higher level in MDA-MB-231 (6.7), ZR-75-1 (7.1), Colo 
Table 4: Ser/Thr: $\alpha$ GalNAc- and GIcNAc: $\beta 1-3$ and $\beta 1-4$ GalNAc-Transferase activities in human cancer cell lines.

\begin{tabular}{|c|c|c|c|}
\hline \multirow[b]{2}{*}{ Cancer Cells } & \multicolumn{3}{|c|}{ Incorporation of $\left[6-{ }^{3} \mathrm{H}\right]$ GalNAc into the acceptor $\left(\mathrm{CPM} \times 10^{-4}\right)$ catalyzed by $1 \mathrm{mg}$ protein of the solubilized cell extract } \\
\hline & $\begin{array}{l}\text { aGalNAc-T: Ser/thr peptides (Biogel P2 } \\
\text { Peak I fraction) }\end{array}$ & $\begin{array}{c}\text { BGalNAc-T: Galß1-3 (GIcNAc } \beta 1-6) \text { GalNAc } \alpha-O-A l \text { (Biogel } \\
\text { P2 Peak II fraction) }\end{array}$ & $\begin{array}{l}\text { Enzyme level in folds: } \alpha \text { GalNAc- T vs } \\
\qquad \text { BalNAc-T }\end{array}$ \\
\hline \multicolumn{4}{|l|}{$\begin{array}{l}\text { Breast } \\
\text { Cancer }\end{array}$} \\
\hline T47D & 11.4 & 1.3 & 8.8 \\
\hline MDA-MB-231 & 13 & 6.7 & 1.9 \\
\hline ZR-75-1 & 23.4 & 7.1 & 3.3 \\
\hline DU4475 & 5.8 & 2.6 & 2.2 \\
\hline MDA-MB-4355 & 7.7 & 2.1 & 3.7 \\
\hline $\begin{array}{l}\text { MDA-435/ } \\
\text { LCC6 }\end{array}$ & 12.5 & 4.4 & 2.8 \\
\hline \multicolumn{4}{|l|}{ Colon Cancer } \\
\hline SW1116 & 15 & 3.9 & 3.9 \\
\hline LS180 & 5.7 & 6.4 & 0.9 \\
\hline \multicolumn{4}{|l|}{$\begin{array}{l}\text { Ovarian } \\
\text { Cancer }\end{array}$} \\
\hline SW626 & 8.2 & 5.6 & 1.5 \\
\hline PA-1 & 14.6 & 6.7 & 2.2 \\
\hline \multicolumn{4}{|l|}{ Leukemia } \\
\hline HL60 & 9.9 & 2.8 & 3.5 \\
\hline \multicolumn{4}{|l|}{$\begin{array}{l}\text { Hepatic } \\
\text { Cancer }\end{array}$} \\
\hline HepG2 & 9.1 & 3.6 & 2.5 \\
\hline \multicolumn{4}{|l|}{$\begin{array}{l}\text { Prostate } \\
\text { Cancer }\end{array}$} \\
\hline
\end{tabular}

205 (7.2), LS180 (6.4), SW626 (5.6), PA-I (6.7) and LNCaP (18.1) as compared to other cell lines (Table 3 ).

GIcNAc: $\beta 1-4$ GalNAc transferase activities of cancer cell lines towards the synthetic acceptor GIcNAc $\beta 1-6$ (Galß13) GalNAca-O-Al as determined by WGA-Agarose tight binding and also compared with VVL- Agarose binding

Figure 4 and 5 present the affinity chromatography profiles of Biogel P2 fraction II containing $\left[6-{ }^{3} \mathrm{H}\right]$ GalNAc-yl product from GlcNAc $\beta 1-6$ (Gal $\beta 1-3)$ GalNAca-O-Al from the fractionation on WGA-Agarose and VVL-Agarose column, respectively. The data obtained from these fractionations are given in Table 5. In this context it is important to note that for the conversion of UDPGalNAc to UDP-GlcNAc by UDP-Glc-4-epimerase, Daenzer et al. (2012) used the reaction mixture containing $100 \mathrm{mM}$ glycine buffer $\mathrm{pH} 8.7,1.6 \mathrm{mM}$ UDP-GalNAc and $0.5 \mathrm{mM}$ NAD. As our reaction conditions are quite different, there is no possibility of UDP-GalNAc being converted to UDP-GlcNAc.

In all cases except for Colo 205, VVL-Agarose binding gave higher values as compared to the corresponding values of WGA-Agarose binding. This discrepancy is explainable by the fact that WGAAgarose binds tightly and strictly only GalNAc $\beta 1-4$ GlcNAc moiety whereas VVL-Agarose binds, in addition to GalNAc $\beta 1-4 \mathrm{GlcNAc}$, also aGalNAc containing small peptides that could be present as a very minor contaminant in Biogel P2 Peak II fractions. From the highly reliable values from the WGA-Agarose binding, it is evident that the breast cell lines ZR-75-1, DU4475 and MDA-MB-435S and the ovarian cell lines PA-1 express respectively lower GlcNAc: $\beta 1$ 4GalNAc transferase activities as follows: $26.6 \%, 33.6 \%, 30.7 \%$ and $22.1 \%$ whereas other cell lines exhibit this activity in the range $54.0 \%$ to $89.6 \%$.

\section{Detection of $\beta 1-3$ Galactosidase activity at neutral $\mathrm{pH}$}

When Biogel P2 Peak II fractions containing $\left[6-{ }^{3} \mathrm{H}\right]$ GalNAc $\beta 1-3 / \beta 1-4$ GlcNAc $\beta 1-6$ (Gal $\beta 1-3$ ) GalNAca-O-Al were subjected to PNA-Agarose chromatography with the anticipation of $100 \%$ binding of the $\left[6-{ }^{3} \mathrm{H}\right]$ GalNAc-yl product to the PNA-Agarose column, it was found that it contained both PNA binding and non-binding fractions indicating that $\beta 1-3$ linked Gal had been hydrolyzed during incubation with the cell extract to a variable extent in the case of all cell lines examined. As Gal $\beta 1-3 \mathrm{GalNAc \alpha}-\mathrm{OBn}$ and 3-O-MeGal $\beta 1-4$ GlcNAc $\beta 1-6$ (Gal $\beta 1-3)$ GalNAca-O-Bn were $100 \%$ inactive as acceptors for cancer cells $\beta$ GalNAc transferases, the $\beta 1-3 \mathrm{Gal}$ is available for the action of cancer cell $\beta$-galactosidase. The fractionation profiles on PNA-Agarose are presented in Figure 6. The data on PNAAgarose binding and non-binding fractions from Figure 6 are given in Table 6. Further, the separation of the products presents in Biogel P2 Peak II fraction was also carried out by thin layer chromatography. Quantitation of the two radioactive products was made by scrapping the silica gel $(0.5 \mathrm{~cm}$ width segments) and soaking in $2 \mathrm{ml}$ water 


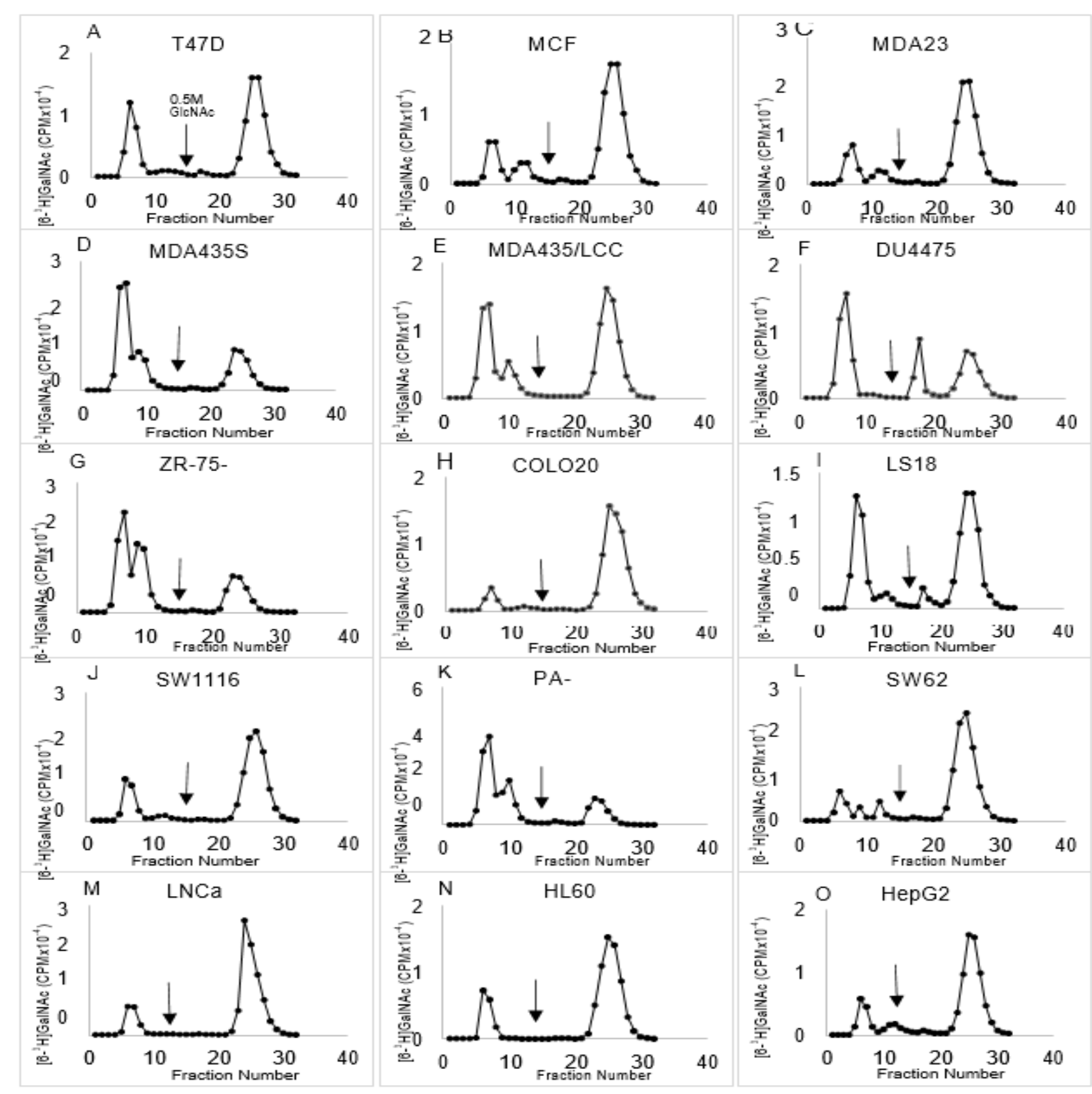

Figure 4: WGA-agarose affinity chromatography of Biogel P2 Peak II Fraction

A) T47D; B) MCF-7; C) MDA-MB-231; D) MDA-MB-435 S; E) MDA-MB-435/LCC6; F) DU4475; G) ZR-75-1; H) Colo 205; I) LS 180; J) SW 1116; K) PA-1; L) SW 626; M) HL 60; N) HepG2.

followed by liquid scintillation counting. The TLC separation of the products is presented in Table 8 and the data obtained from this table is presented in Table 6 as percent of the radioactivity present in each component from the total CPM of the two components of each cell lines. These TLC values closely resembled the percentage of PNAAgarose binding and non-binding fractions in spite of the fact that the TLC data is not expected to be $100 \%$ quantitative as compared to the PNA-Agarose data. We identified component $\mathrm{C} 2$ as $\left[6-{ }^{3} \mathrm{H}\right]$ GalNAc $\beta 1$ - 3/4GlcNAc $\beta 1-6 \mathrm{GalNAc} \alpha-\mathrm{O}-\mathrm{Al}$ as follows: When Gal $\beta 1$ 3(GlcNAc $\beta 1-6)$ GalNAca-Ol-O-Al was treated with recombinant $\beta 1$ - 3galactosidase (Calbiochem) for complete conversion to GlcNAc $\beta 1-6$ GalNAca-Ol-O-Al and then subjected to $\left[6-{ }^{3} \mathrm{H}\right]$ GalNAc-ylation by using separately PA-1 and LNCaP extracts, the radioactivity moved as a single component in TLC with the mobility of component $\mathrm{C} 2$ in both cases (not shown). The conversion of T-epitope to Tn at neutral $\mathrm{pH}$ catalyzed by the $\beta$-Galactosidase present in the cell extracts (Table 6 last column) was calculated from the PNA non-binding data and considering that the incubation mixture contained $3 \mu \mathrm{mol}$ of the acceptor GlcNAc $\beta 1-6$ (Gal $\beta 1-3$ ) GalNAca-O-Al and $5 \mathrm{mg}$ protein from each cell extract. The human cancer cell lines thus contained 


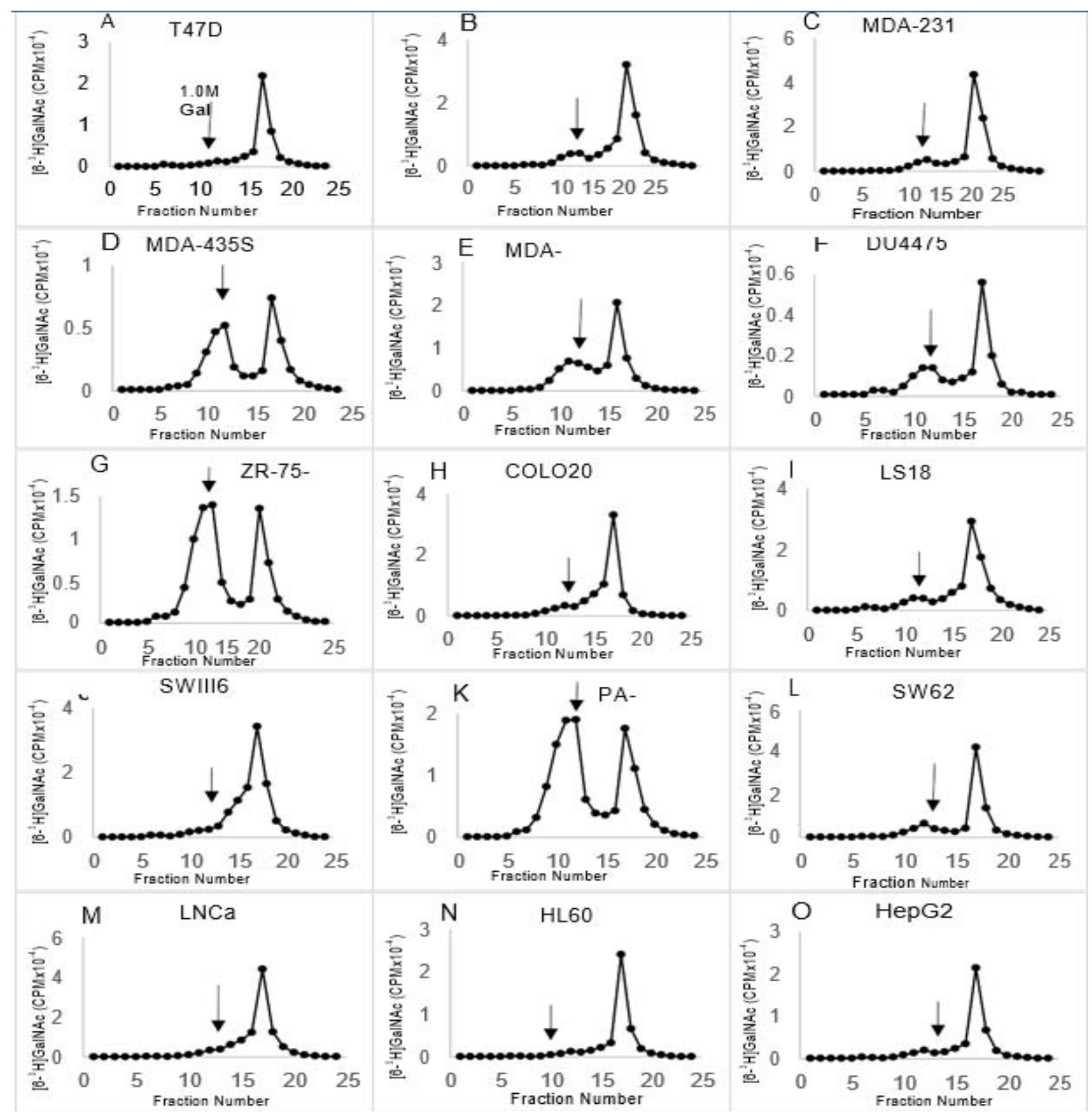

Figure 5: VVL-agarose affinity chromatography of Biogel P2 Peak II Fraction.

A) T47D; B) MCF-7; C) MDA-MB-231; D) MDA-MB-435 S; E) MDA-MB-435/LCC6; F) DU4475; G) ZR-75-1; H) Colo 205; I) LS 180; J) SW 1116; K) PA-1; L) SW 626; M) HL 60; N) HepG2.

quite a high level of neutral $\beta$-Galactosidase activity exhibiting the ability to catalyze the hydrolysis of $0.18-0.59 \mu \mathrm{mol}$ T-epitope per mg protein of the cell extracts (e.g., T47D: $0.6 \mu \mathrm{mol} X 98.7 \%$ (PNAAgarose non-binding $)=0.59 \mu \mathrm{mol}$; MDA-MB-231: $0.6 \mu \mathrm{mol}$ X 46\% $=$ $0.28 \mu \mathrm{mol})$.

\section{Determination of GIcNAc}

$\beta 1-3 G a l N A c$ and GlcNAc: $\beta 1-4$ GalNAc transferase activities utilizing the universal acceptor GlcNAc $\beta$-O-Bn for both enzymes, the tight binding of GalNAc $\beta 1-4 \mathrm{GlcNAc}$ to WGA-agarose and the weak binding of GalNAc $\beta 1-3$ GlcNAc to VVL-agarose: The WGAagarose tight binding and VVL-agarose weak binding respectively of the products $\left[6-{ }^{3} \mathrm{H}\right]$ GalNAc $\beta 1-4-$ and $\beta 1-3-G l c N A c \beta-O-B n$ from the exogenous acceptor GlcNAc $\beta-\mathrm{O}-\mathrm{Bn}$, isolated by Sep-Pak C18 method were used for quantitating $\beta 1-4$ and $\beta 1-3$ GalNAc-T activities. When $\left[6-{ }^{3} \mathrm{H}\right]$ GalNAc $\beta 1-3 / \beta 1-4 \mathrm{GlcNAc} \beta-\mathrm{O}-\mathrm{Bn}$ isolated by using PA-1 and LNCaP extracts as enzyme sources were subjected to galacdose oxidase-horse-radish peroxidase treatment, these products 
Table 5: Determination of GlcNAc: $\beta 1-4$ GalNAc-transferase activity in cancer cell lines by utilizing the binding of $\left[6-{ }^{3} \mathrm{H}\right] \mathrm{GalNAc-yl}$ product from $\mathrm{GlcNAc} \beta 1-6$ Gal $(\beta 1-3)$ GalNAca-O-Al to WGA-Agarose as well as VVL- Agarose affinity columns

\begin{tabular}{|c|c|c|}
\hline \multirow{2}{*}{ Cancer Cells } & \multicolumn{2}{|c|}{$\left[6-{ }^{3} \mathrm{H}\right]$ GalNAc-yl product from GlcNAc $\beta 1-6$ ( $\left.\beta 1-3\right)$ GalNAc $\alpha-O-A l$ (Biogel P2 Peak II fraction) } \\
\hline & WGA-Agarose binding (\%) & VVL-Agarose binding (\%) \\
\hline \multicolumn{3}{|l|}{ Breast Cancer } \\
\hline T47D & 64.1 & 90.6 \\
\hline MDA-MB-231 & 74.2 & 84.2 \\
\hline MCF-7 & 72.4 & 82.9 \\
\hline ZR-75-1 & 26.6 & 37.6 \\
\hline DU4475 & 33.6 & 66.6 \\
\hline MDA-MB-4355 & 30.7 & 48 \\
\hline MDA-435/LCC6 & 54 & 54.4 \\
\hline \multicolumn{3}{|l|}{ Colon Cancer } \\
\hline COLO205 & 89.6 & 84.9 \\
\hline SW1116 & 75.8 & 98.2 \\
\hline LS180 & 56.1 & 81.5 \\
\hline \multicolumn{3}{|l|}{ Ovarian Cancer } \\
\hline SW626 & 68.3 & 75.3 \\
\hline PA-1 & 22.1 & 37.1 \\
\hline \multicolumn{3}{|l|}{ Leukemia } \\
\hline HL60 & 77.4 & 90.2 \\
\hline \multicolumn{3}{|l|}{ Hepatic Cancer } \\
\hline HepG2 & 75.9 & 84.5 \\
\hline \multicolumn{3}{|l|}{ Prostate Cancer } \\
\hline LNCaP & 82.9 & 99 \\
\hline
\end{tabular}

Table 6: Identification of $\beta 1-3$ Galactosidase activity converting T-antigenic structure (Gal $\beta 1-3$ GalNAc $\alpha-$ ) to Tn (GalNAc $\alpha-$ ) in human cancer cell lines.

\begin{tabular}{|c|c|c|c|c|c|}
\hline \multirow{2}{*}{$\begin{array}{l}\text { Cancer } \\
\text { Cells }\end{array}$} & \multicolumn{2}{|c|}{$\begin{array}{c}\text { GalNAc } \beta 1-3 / 4 \text { GlcNAc } \beta 1-6 \\
\text { GalNAc } \alpha-O-A I\end{array}$} & \multicolumn{2}{|c|}{$\begin{array}{l}\text { GaINAc } \beta 1-3 / 4 \text { GIcNAc } \beta 1-6 \\
(\text { Gal } \beta 1-3) \text { GalNAc } \alpha-O-A I\end{array}$} & \multirow{2}{*}{$\begin{array}{l}\text { aConversion of } \mathrm{T} \text { epitope to } \mathrm{Tn} \text { at neutral } \mathrm{pH} \text { catalyzed by } \beta \text { - } \\
\text { Galactosidase present in } 1 \mathrm{mg} \text { protein of the cell extract ( } \mu \mathrm{mol})\end{array}$} \\
\hline & $\begin{array}{l}\text { PNA-Agarose } \\
\text { non-binding (\%) }\end{array}$ & $\begin{array}{c}\text { TLC } \\
\text { Component } \\
\text { C2 (\%) }\end{array}$ & $\begin{array}{l}\text { PNA Agarose } \\
\text { binding (\%) }\end{array}$ & $\begin{array}{c}\text { TLC } \\
\text { Component } \\
\text { C2 (\%) }\end{array}$ & \\
\hline \multicolumn{6}{|l|}{$\begin{array}{l}\text { Breast } \\
\text { Cancer }\end{array}$} \\
\hline T47D & 98.7 & 88 & 1.3 & 12 & 0.59 \\
\hline $\begin{array}{l}\text { MDA- } \\
\text { MB-231 }\end{array}$ & 46 & & 54 & & 0.28 \\
\hline MCF-7 & 67.6 & & 32.4 & & 0.41 \\
\hline ZR-75-1 & 55.5 & 47.7 & 44.5 & 52.3 & 0.35 \\
\hline DU4475 & 45 & & 55 & & 0.27 \\
\hline $\begin{array}{l}\text { MDA-MB- } \\
435 \mathrm{~S}\end{array}$ & 46.3 & & 53.7 & & 0.28 \\
\hline $\begin{array}{l}\text { MDA-435/ } \\
\text { LCC6 }\end{array}$ & 41.8 & & 58.2 & & 0.25 \\
\hline \multicolumn{6}{|l|}{$\begin{array}{l}\text { Colon } \\
\text { Cancer }\end{array}$} \\
\hline COLO205 & 29.3 & 26.6 & 70.7 & 73.4 & 0.18 \\
\hline SW1116 & 70.1 & 61.6 & 29.9 & 38.4 & 0.42 \\
\hline LS180 & 55.1 & 35.8 & 44.9 & 64.2 & 0.33 \\
\hline \multicolumn{6}{|l|}{$\begin{array}{l}\text { Ovarian } \\
\text { Cancer }\end{array}$} \\
\hline SW626 & 94.9 & 89.6 & 5.1 & 10.4 & 0.57 \\
\hline PA-1 & 53.2 & 40.1 & 46.8 & 59.9 & 0.32 \\
\hline \multicolumn{6}{|l|}{ Leukemia } \\
\hline HL60 & 20.3 & 11.6 & 79.7 & 88.4 & 0.12 \\
\hline \multicolumn{6}{|l|}{$\begin{array}{l}\text { Hepatic } \\
\text { Cancer }\end{array}$} \\
\hline HepG2 & 80 & 74.4 & 20 & 25.6 & 0.48 \\
\hline \multicolumn{6}{|l|}{$\begin{array}{l}\text { Prostate } \\
\text { Cancer }\end{array}$} \\
\hline LNCaP & 29.7 & 19.5 & 70.3 & 80.5 & 0.18 \\
\hline
\end{tabular}

aCalculation was based on $3 \mu \mathrm{mol}$ Galß1-3 (GIcNAcß1-6) GalNAca-O-Al and 5mg protein present in the incubation mixture of each cell extract and PNA-Agarose nonbinding material in percent as reported in column 2 of this table. 


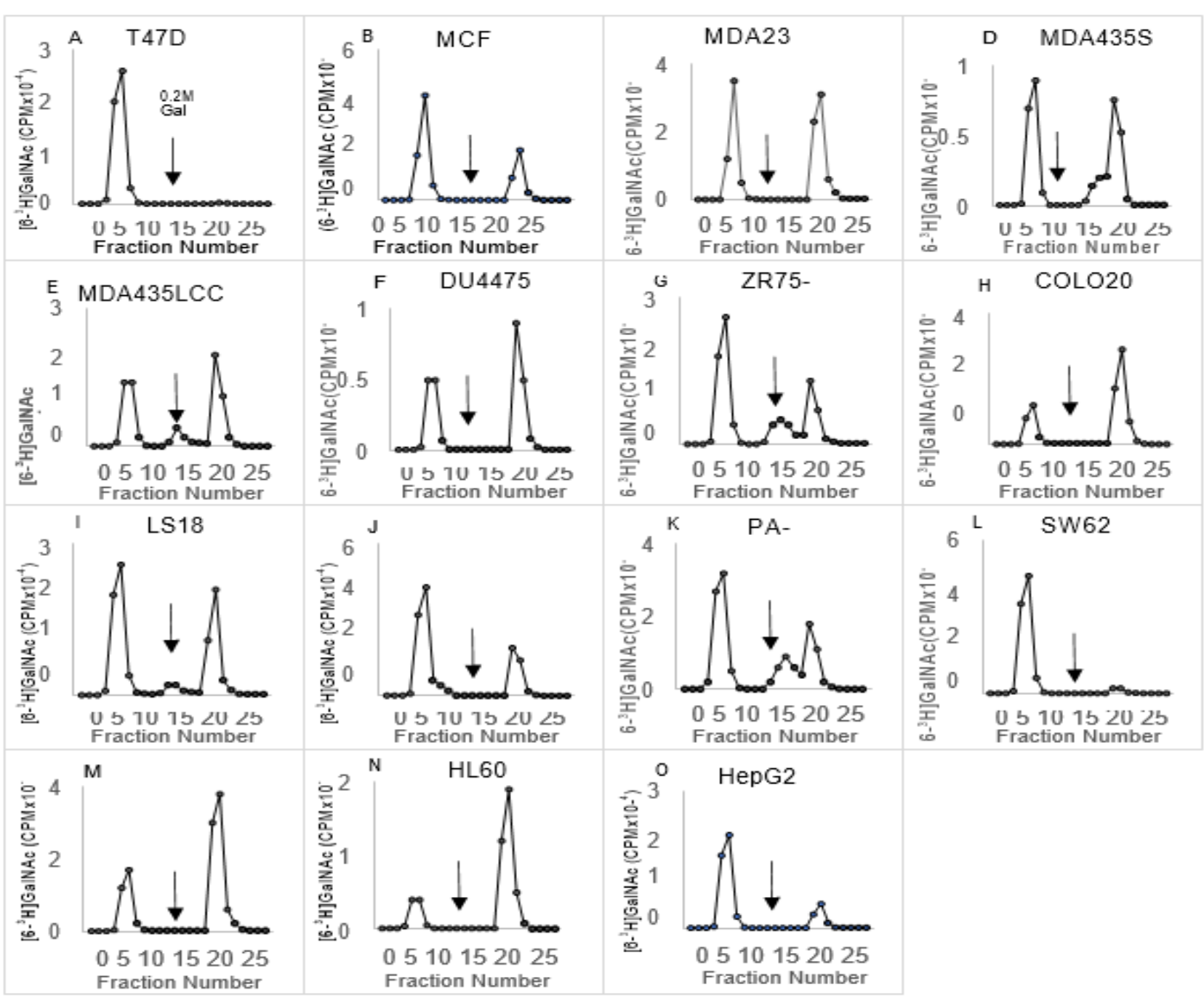

Figure 6: Separation of $\left[6-{ }^{3} \mathrm{H}\right]$ GalNAc-yl products present in Biogel P2 Peak II Fraction by affinity chromatography on PNA-agarose.

A) T47D; B) MCF-7; C) MDA-MB-231; D) MDA-MB-435 S; E) MDA-MB-435/LCC6; F) DU4475; G) ZR-75-1; H) Colo 205; I) LS 180; J) SW 1116; K) PA-1; L) SW 626; M) HL 60; N) HepG2.

lost $\mathrm{C} 6-{ }^{3} \mathrm{H}$ label showing the absence epimerase reaction under our incubation conditions for GalNAc-T activity.

WGA-Agarose and VVL-Agarose affinity chromatographic profiles of $\left[6-{ }^{3} \mathrm{H}\right]$ GalNAc-yl products from GlcNAc $\beta-\mathrm{O}-\mathrm{Bn}$ are presented in Figure 7 and 8 respectively. The product $\left[6{ }^{-} \mathrm{H}\right]$ GalNAc $\beta 1-4$ GlcNAc $\beta-O-B n$ exhibited tight binding to WGAagarose whereas $\left[6-{ }^{3} \mathrm{H}\right]$ GalNAc $\beta 1-3$ GlcNAc $\beta-\mathrm{O}-\mathrm{Bn}$ showed weak binding to VVL-agarose. The values for the binding obtained from these Figures are given in Table 7. The fold of activity for $\beta 1-4 \mathrm{GalNAc}$ transfer as compared to $\beta 1-3$ GalNAc transfer are presented in Table 6 last Column. These values for DU-4475 and MDA- MB-435S (breast cancer), PA-1 (ovarian cancer), LNCaP, PC3 and DU145 (prostate cancer), EG7 (lymphoma), and GL261-OVA (Glioma) were 0.1, 0.6, $0.3,0.2,0.4,0.3,0.3$ and 0.5 respectively indicating the predominance of $\beta 1$ - 3GalNAc transferase activity in these cell lines. Among the remaining cell lines, T47D, MDA-MB-231 and MCF-7 (breast cancer), Colo205 and SW1116 (colon cancer) and U87GB (Glioblastoma) showed high $\beta 1-4$ GalNAc transferase activity which exceeded 2 -fold of $\beta 1-3$ GalNAc transferase activity in the range 2.3-4.9. It needs to be mentioned that in Sep-Pak C18 fractionation, most of the aGalNAc bearing polypeptides present in the incubation mixture containing the $\left[6-{ }^{3} \mathrm{H}\right]$ GalNAc-Ylated product from the exogenous acceptor GlcNAc-B-O-Bn were eliminated in the exhaustive water washings of Sep-Pak C18 cartridge.

Measuring the level of $\beta 1-3$ and $\beta 1-4$ GalNAc transferase activities present in some cancer cell lines and tissue specimens by using HPLC for the separation of $\left[6-{ }^{3} \mathrm{H}\right]$ GalNAc-yl products resulting from the acceptor GIcNAc $\beta$ O-Bn

The HPLC data is presented in Figure 9. The separation of synthetic compounds in HPLC is shown in Figure 9A. GalNAc $\beta 1$ 6GlcNAc $\beta-\mathrm{O}-\mathrm{Bn}$, GalNAc $\beta 1-3 \mathrm{GlcNAc} \beta-\mathrm{O}-\mathrm{Bn}$ and GalNAc $\beta 1-$ $4 \mathrm{GlcNAc} \beta-\mathrm{O}-\mathrm{Bn}$ are emerging respectively from the column in the same sequence. As shown by the analysis with WGA-Agarose and 


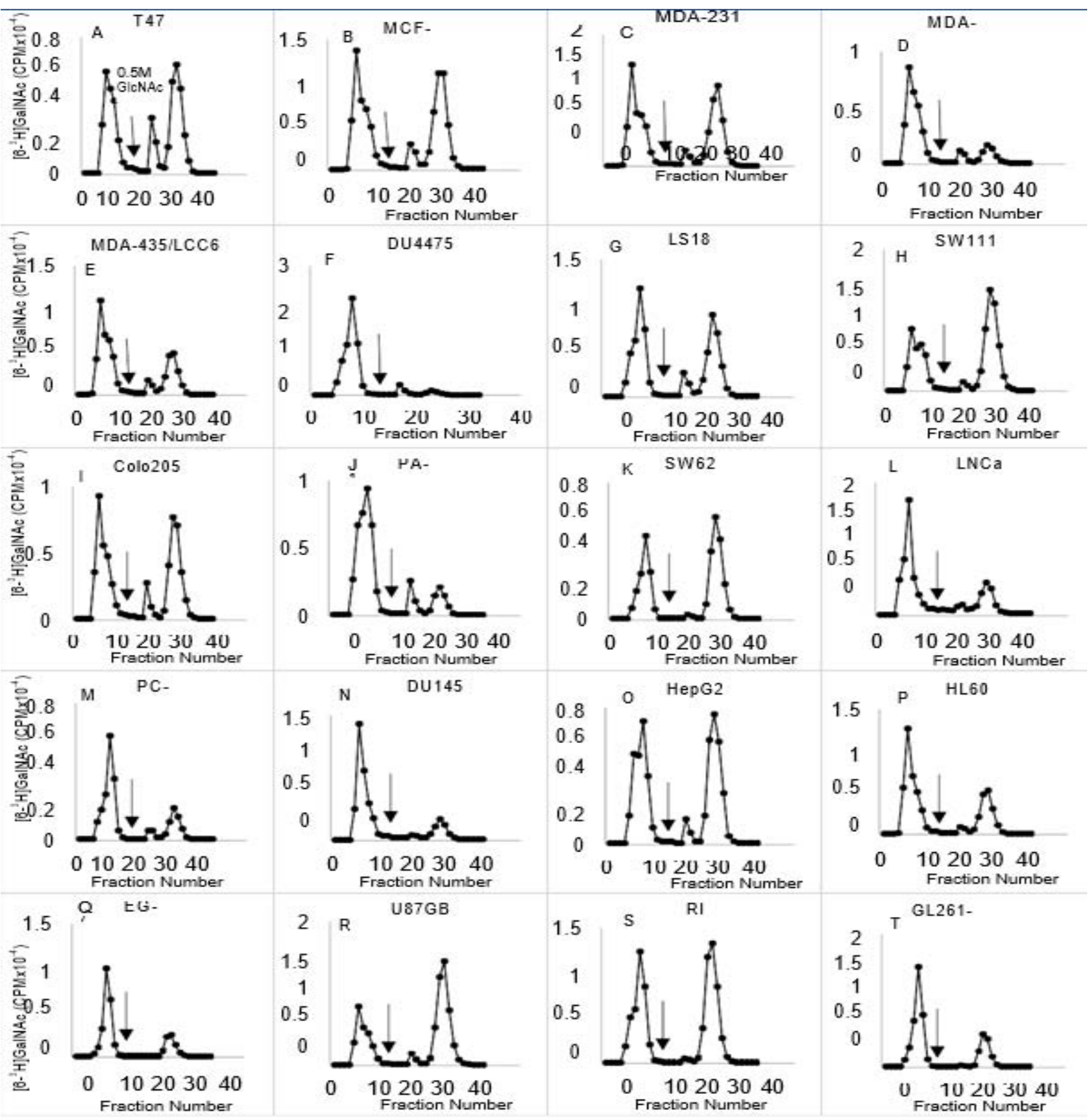

Figure 7: WGA- agarose affinity chromatography of $\left[6-{ }^{3} \mathrm{H}\right]$ GalNAc-yl products from GlcNAc $\beta-\mathrm{O}-\mathrm{Bn}$.

A) T47D; B) MCF-7; C) MDA-MB-231; D) MDA-MB-435 S; E) MDA-MB-435/LCC6; F) DU4475; G) LS180; H) SW1116; I) Colo 205; J) PA-1; K) SW 626; L) LNCaP; M) PC-3; N) DU145; O) HepG2; P) HL60; Q) EG-7; R) U87GB; S) RIF; T) GL261-OVA.

VVL- Agarose affinity chromatography, the HPLC data indicate that the prostate cancer cell lines LNCaP, PC3 and DU145 (Figure 9B9D), the breast cell lines DU4475 and MDA-MB-435S (Figure 9E and 9G) and the ovarian cell lines PA1 and SW626 (Figure 9I and 9J) contained significant $\beta 1-3 \mathrm{GalNAc}$ transferase activity in contrast to the predominant $\beta 1-4 \mathrm{GalNAc}$ transferase activity in T47D and Colo205 (Figure 9F and 9H). The HPLC analysis of some tumor specimens for $\beta 1-3 / \beta 1-4$ GalNAc transferase activities indicated that the two pancreatic tumor specimens (Figure 9N and 9O) and one gastric tumor specimen (Figure 9P) express significantly high level of $\beta 1-3$ GalNAc transferase activity as compared to its level in three prostate tumor specimens (Figure 9K and 9L) and one normal testes specimen (Figure 9M). The HPLC profiles (Figure 9) further showed either negligible or extremely low level of GalNAc $\beta 1-6 \mathrm{GlcNAc} \beta-\mathrm{O}-$ $\mathrm{Bn}$ in all cases examined. 
Table 7: Determination of the products $\left[6-{ }^{3} \mathrm{H}\right]$ GalNAc $\beta 1-3 \mathrm{GIcNAc} \beta-\mathrm{O}-\mathrm{Bn}$ and $\left[6-{ }^{3} \mathrm{H}\right]$ GalNAc $\beta 1-4 \mathrm{GIcNAc} \beta-\mathrm{O}-\mathrm{Bn}$ resulting from GlcNAc $\beta-\mathrm{O}-\mathrm{Bn}$ by the action of GalNAc-transferases in human cancer cell lines.

\begin{tabular}{|c|c|c|c|}
\hline Cancer Cells & $\begin{array}{c}\text { WGA-Agarose Tight Binding (\%) GalNAc } \beta 1-4 \\
\text { GlcNAc } \beta-O-B n\end{array}$ & $\begin{array}{l}\text { VVL-Agarose Weak Binding (\%) GalNAc } \beta-3 \\
\text { GlcNAc } \beta-O-B n\end{array}$ & $\begin{array}{c}\text { Enzyme levels in fold: } \beta 1-4 \text { GalNAc-T vs } \\
\beta 1-3 \text { GalNAc-T }\end{array}$ \\
\hline \multicolumn{4}{|l|}{ Breast Cancer } \\
\hline T47D & 44.8 & 15 & 3 \\
\hline MDA-MB-231 & 44 & 19.1 & 2.3 \\
\hline MCF-7 & 44.2 & 16.3 & 2.7 \\
\hline DU4475 & 5.3 & 63.7 & 0.1 \\
\hline MDA-MB-435S & 15.7 & 25.6 & 0.6 \\
\hline MDA-435/LCC6 & 30 & 24.6 & 1.2 \\
\hline \multicolumn{4}{|l|}{ Colon Cancer } \\
\hline COLO205 & 44.4 & 15.1 & 2.9 \\
\hline SW1116 & 58.6 & 17.6 & 3.3 \\
\hline LS180 & 36.7 & 34.3 & 1.1 \\
\hline \multicolumn{4}{|l|}{$\begin{array}{l}\text { Ovarian } \\
\text { Cancer }\end{array}$} \\
\hline SW626 & 58 & 32.1 & 1.8 \\
\hline PA-1 & 14.1 & 44.2 & 0.3 \\
\hline \multicolumn{4}{|l|}{ Leukemia } \\
\hline HL60 & 32.1 & 22.6 & 1.4 \\
\hline \multicolumn{4}{|l|}{$\begin{array}{l}\text { Hepatic } \\
\text { Cancer }\end{array}$} \\
\hline HepG2 & 48.1 & 25.5 & 1.9 \\
\hline \multicolumn{4}{|l|}{$\begin{array}{l}\text { Prostate } \\
\text { Cancer }\end{array}$} \\
\hline LNCaP & 16.9 & 76.1 & 0.2 \\
\hline PC3 & 24.5 & 56 & 0.4 \\
\hline DU145 & 18.7 & 66.5 & 0.3 \\
\hline U87GB & 61.7 & 12.6 & 4.9 \\
\hline \multicolumn{4}{|l|}{ (Glioblastoma) } \\
\hline $\begin{array}{c}\text { EG7 } \\
\text { (Lymphoma) }\end{array}$ & 24.5 & 70.5 & 0.3 \\
\hline RIF & 52.7 & 34.7 & 1.5 \\
\hline \multicolumn{4}{|l|}{ (Fibrosarcoma) } \\
\hline GL261-OVA & 28.2 & 60.9 & 0.5 \\
\hline (Glioma) & & & \\
\hline
\end{tabular}

\section{Discussion}

Multiple sequential and competitive enzymatic pathways govern the synthesis of glycan structures of the cell surface and secreted molecules $[35,36]$. The glycans change dynamically responding to small variation in the extracellular environment and intracellular events [37]. Changes in glycan structures, generally but not uniformly, correlate with alteration in transcript abundant for the corresponding biosynthetic enzymes [37]. The present study was aimed to find any distinct variation and correlation in the expression of GalNAc-Ts in conjunction with other glycosyltransferases-activities associated with $\mathrm{O}$-glycan biosynthesis among various cancers by examining a wide range of human cancer cell lines.

\section{Specificities of GalNAc-T}

The present study showed in cancer cells that Gal $11-3$ GalNAc
(T-hapten) and 4-FGlcNAc do not serve as acceptors for GalNAc-T but the enzymatic transfer of GalNAc to LacNAc occurs to some extent indicating the possible minor extension of LacNAc chain by GalNAc. GlcNAc $\beta 1-4$ GlcNAc was shown as a poor acceptor for GalNAc-T due to the fact that $\beta 1-4$ GalNAc transfer is not favored at all due to the structural specificity related constraint as evident from the structure of polylactosamine containing alternate $\beta 1-3$ and $\beta 1-4$ linkages. Further, GlcNAc $\beta 1-4$ GlcNAcdid not accept more GalNAc by the action of $\beta 1-3$ GalNAc-T which is present predominantly in some cancer cell lines as compared to other cancer cell lines (Table 2). It appears that internal $\beta$ linked GlcNAc in general inhibits enzymatic transfer of GalNAc to terminal GlcNAc. While GlcNAc $\beta-(\mathrm{O})-\mathrm{Bn}$ could act as an acceptor for both $\beta 1-3$ and $\beta 1-4$ GalNAc transferases, GlcNAc $\beta 1-6$ GalNAc $\beta-(O)$-Bn could be a favorable acceptor for $\beta 1$ $4 \mathrm{GalNAc}-\mathrm{T}$ as evident from the known structure of mucin core 2 


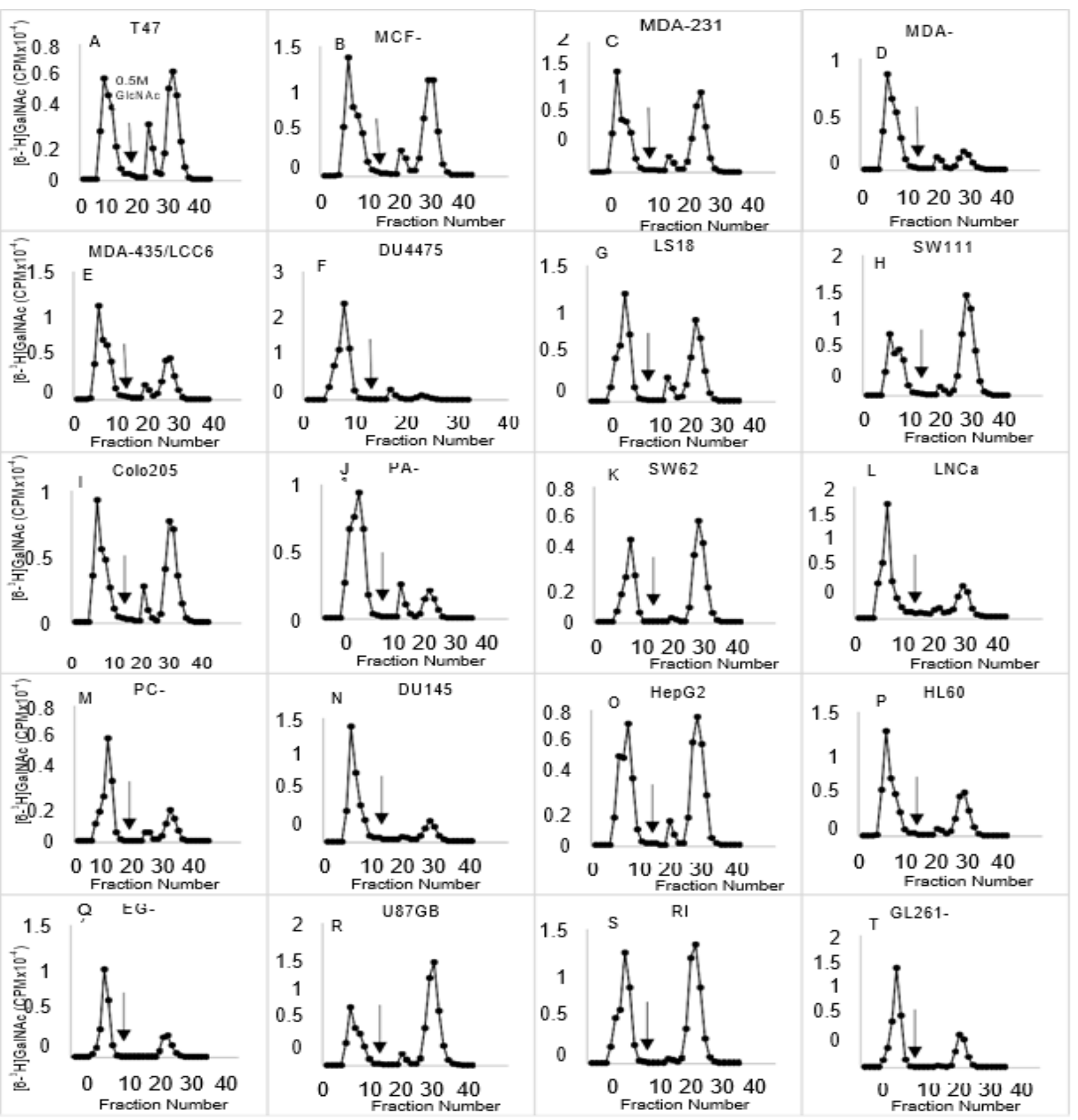

Figure 8: VVL-agarose affinity chromatography of $\left[6-{ }^{3} \mathrm{H}\right]$ GalNAc-yl products from GlcNAcß-O-Bn.

A) T47D; B) MCF-7; C) MDA-MB-231; D) MDA-MB-435 S; E) MDA-MB-435/LCC6; F) DU4475; G) LS180; H) SW1116; I) Colo 205; J) PA-1; K) SW 626; L) LNCaP; M) PC-3; N) DU145; O) HepG2; P) HL60; Q) EG-7; R) U87GB; S) RIF; T) GL261-OVA.

tetrasaccharide namely Gal $\beta 1-4 \mathrm{GlcNAc} \beta 1-6$ (Gal $\beta 1-3)$ GalNAca-, where Gal is attached $\beta 1-4$ to GlcNAc.

Breast cancer cells: The enzymatic transfer of 1.9-8.8 fold of GalNAc to endogenous Ser/Thr containing polypeptides as compared to $\beta$ GalNAc transfer to exogenous acceptor GlcNAc $\beta 1-6(\mathrm{Gal} \beta 1-3)$ GalNAca-O-Al would indicate both the high activity of aGalNAc-T and predominant occurrence of Ser/Thr containing polypeptides in breast cancer cells. DU4475 and MDA-MB-435S were unique among breast cancer cells by expressing a high level of GlcNAc: $\beta 1$ 3 GalNAc-T as compared to $\beta 1-4$ GalNAc-T activity. Very low level of $\alpha 2-3(\mathrm{O})$ sialyltransferase activity was present in DU4475 (0.9) whereas ZR-75-1 (36.8), MDA-MB-435S (25.7) and MDA-MB-435/ LCC6 (17.2) had high level of this enzyme activity. aGalNAc: $\beta 1$ 3Gal-T activity in DU4475 was considerably high (4.7) among breast cancer cell lines. In this context it is to be noted that DU4475 was derived from breast cancer metastatic cutaneous nodule whereas 

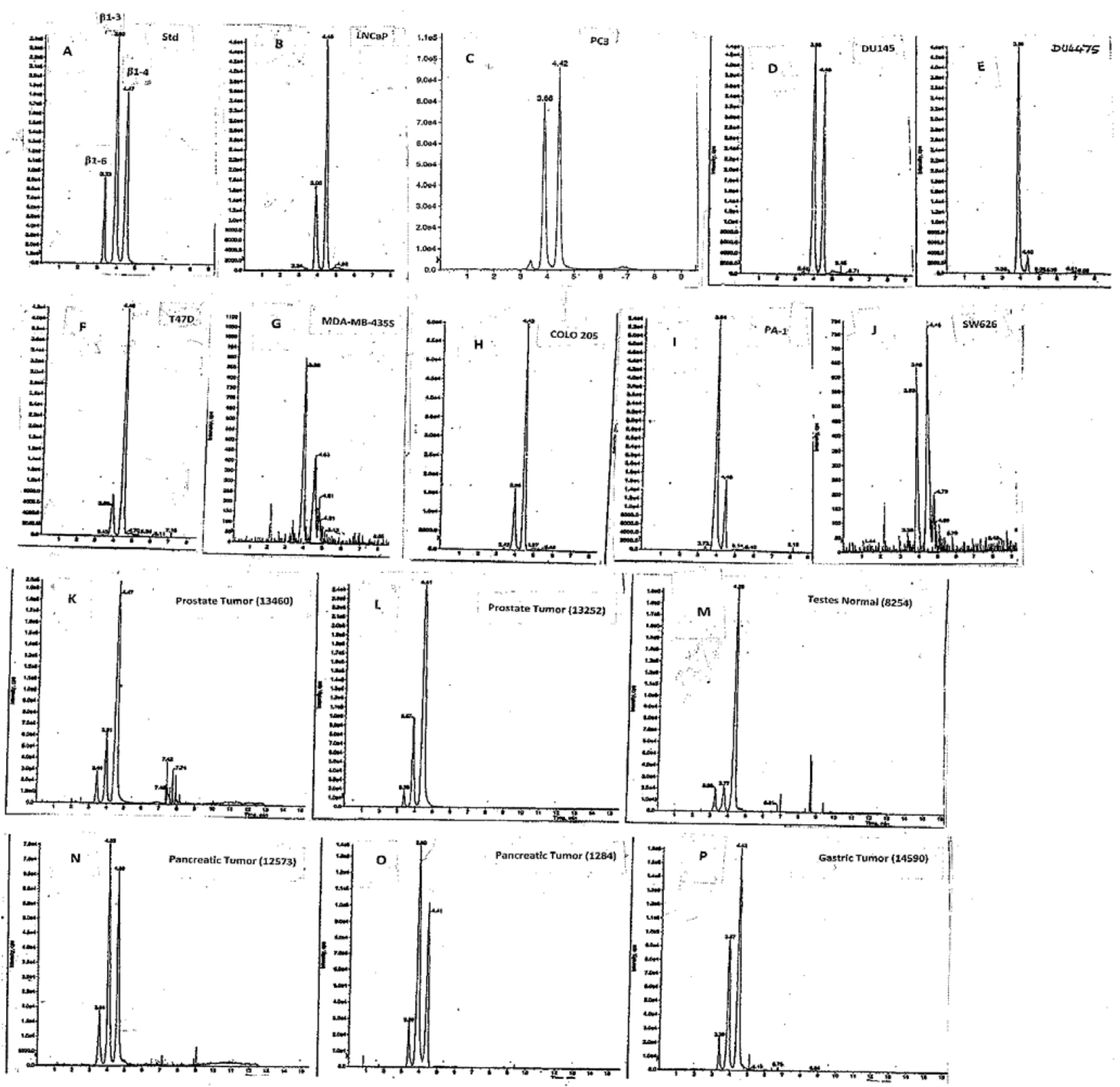

Figure 9: HPLC separation of GalNAc $\beta 1-3$ GIcNAc $\beta-O-B n$, GalNAc $\beta 1-4$ GIcNAc $\beta-O-B n$ and GalNAc $\beta 1-6$ GlcNAc $\beta-O-B n$ formed from GIcNAc $\beta-O-B n$ by $\beta$ GalNAc-T present in cancer cells and tissue specimens.

A) Separation of standards $\left[6-{ }^{3} \mathrm{H}\right]$ GalNAc $\beta 1-3$ GlcNAc $\beta-O-B n,\left[6-{ }^{3} \mathrm{H}\right]$ GalNAc $\beta 1-4$ GlcNAc $\beta-O-B n$ and

[6- ${ }^{3} \mathrm{H}$ ] GalNAcß1-6 GlcNAcß-O-Bn; B) LNCaP; C) PC3; D) DU145; E) DU4475; F) T47D; G) MDA-MB-435S; H) Colo205; I) PA-1; J) SW626; K) Prostate tumor (13460); L) Prostate tumor (13252); M) Testes normal (8254); N) Pancreatic tumor (12573); O) Pancreatic tumor (1284); P) Gastric tumor (14590).

other breast cancer cells were established by cultivation of cells from the pleural effusion of breast cancer patients. MDA-MB-435S which is not tumorigenic in athymic nude mice had low $\beta 1-3 \mathrm{Gal}-\mathrm{T}$ (1.1) and $\beta 1-4 \mathrm{Gal}-\mathrm{T}$ (8.0) activities in contrast to high activities of these enzymes (4.5 and 40.0) in MDA-MB-435/LCC6, which grow as both malignant ascites and solid tumors in vivo in nude mice and nude rats.

Further it is interesting to note that MDA-MB-435/LCC6 exhibited more $\alpha$ GalNAc transfer than MDA-MB435S (12.5 vs. 7.7).
Thus, it is conceivable that in general, breast cancer cells exhibit a significant elevation in the levels of Ser/Thr: $\alpha$ GalNAc-T, aGalNAc: $\beta 1$ 3Gal-T, GlcNAc: $\beta 1-4 \mathrm{Gal}-\mathrm{T}$, neutral $\beta 1-3$ galactosidase converting $\mathrm{T}$ to $\mathrm{Tn}$ and decreased level of $\alpha 2-3(\mathrm{O}) \mathrm{ST}$.

Colon cancer cells: Although all colon cancer cells showed similar levels of $\beta$ GalNAc-T activity, only SW1116 contained a high level of a GalNAc-T activity (15.0; Figure 10C) and highly heterogenous Ser/ Thr containing polypeptides (Figure $3 \mathrm{~J}$ ). The levels of $\beta 1-3 \mathrm{Gal}-\mathrm{T}, \alpha 2-3$ (O)ST and $\beta 1-4$ Gal-T as well as neutral $\beta 1-3$ galactosidase activities 
Table 8: Thin layer chromatography of [6-3H] GalNAc-YI products from Galß1-3 (GlcNAcß1-6) GalNAca- O-Al (Biogel P2 Peak II Fraction).

\begin{tabular}{|c|c|c|c|c|c|c|c|c|c|c|c|c|}
\hline 20 & 478 & 211 & 201 & 61 & 20 & 98 & 87 & 111 & 445 & 20 & 131 & 94 \\
\hline 19 & 458 & 205 & 364 & 103 & 19 & 129 & 75 & 114 & 512 & 19 & 221 & 155 \\
\hline 18 & 342 & 196 & 268 & 85 & 18 & 95 & 105 & 139 & 437 & 18 & 253 & 167 \\
\hline 17 & 258 & 184 & 202 & 113 & 17 & 116 & 91 & 125 & 313 & 17 & 282 & 217 \\
\hline 16 & 326 & 185 & 214 & 91 & 16 & 113 & 112 & 121 & 424 & 16 & 252 & 238 \\
\hline 15 & 320 & 194 & 207 & 142 & 15 & 138 & 116 & 109 & 460 & 15 & 260 & 230 \\
\hline 14 & 368 & 243 & 226 & 139 & 14 & 98 & 148 & 143 & 375 & 14 & 285 & 250 \\
\hline 13 & 941 & 328 & 240 & 205 & 13 & 130 & 200 & 123 & 3274 & 13 & 243 & 311 \\
\hline 12 & 3568 & 6234 & 875 & 601 & 12 & 215 & 2524 & 1857 & 7803 & 12 & 762 & 274 \\
\hline 11 & 3087 & 7580 & 3542 & 2781 & 11 & 115 & 3485 & 1699 & 1440 & 11 & 2524 & 546 \\
\hline 10 & 397 & 1392 & 2131 & 336 & 10 & 92 & 431 & 283 & 372 & 10 & 412 & 1516 \\
\hline 9 & 298 & 271 & 239 & 136 & 9 & 99 & 152 & 153 & 384 & 9 & 201 & 441 \\
\hline 8 & 3357 & 461 & 569 & 135 & 8 & 839 & 389 & 1536 & 2936 & 8 & 765 & 203 \\
\hline C1 & 6594 & 938 & 4308 & 242 & 7 & 2304 & 1521 & 7213 & 3786 & 7 & 10227 & 1283 \\
\hline 6 & 1409 & 373 & 2304 & 131 & 6 & 346 & 379 & 1867 & 688 & 6 & 3797 & 2740 \\
\hline 5 & 312 & 204 & 272 & 97 & 5 & 110 & 150 & 188 & 283 & 5 & 442 & 471 \\
\hline 4 & 446 & 298 & 277 & 220 & 4 & 148 & 206 & 212 & 314 & 4 & 321 & 291 \\
\hline 3 & 275 & 225 & 151 & 107 & 3 & 117 & 207 & 125 & 236 & 3 & 331 & 215 \\
\hline 2 & 222 & 180 & 115 & 109 & 2 & 76 & 100 & 73 & 219 & 2 & 136 & 176 \\
\hline \multirow[t]{2}{*}{1} & 552 & 259 & 162 & 175 & 1 & 88 & 170 & 90 & 347 & 1 & 159 & 446 \\
\hline & PA-1 & SW626 & ZR-75-1 & T47D & & HL60 & HepG2 & Colo205 & SW1116 & & LNCaP & LS180 \\
\hline C1\% & 59.9 & 10.4 & 52.3 & 12 & & 88.4 & 25.6 & 73.4 & 38.4 & & 80.5 & 64.2 \\
\hline $\mathrm{C} 2 \%$ & 40.1 & 89.6 & 47.7 & 88 & & 11.6 & 74.4 & 26.6 & 61.6 & & 19.5 & 35.8 \\
\hline
\end{tabular}

A) PA-1; B) SW626; C) ZR-75-1; D) T47D; E) HL60; F) HepG2; G) Colo205; H) SW1116; I) LNCaP; J) LS180.

$(6.2,9.6,50.3$ and 0.42$)$ respectively were also higher when compared to these activities in Colo205 and LS180 (Figure 10B and 10C). Thus, some colon cancer cells express higher activities of $\alpha \mathrm{GalNAc}$-T, $\beta 1$ 3Gal-T, $\beta 1-4 \mathrm{Gal}-\mathrm{T}$, and $\alpha 2-3(\mathrm{O}) \mathrm{ST}$ and highly heterogenous Ser/Thr polypeptides.

Ovarian cancer cells: SW626 contained quite heterogenous Ser/ Thr bearing polypeptides (Figure 3L) and higher $\beta$ GalNAc-T activity (Figure 10A) whereas PA1 had higher aGalNAc-T activity and larger molecular size Ser/Thr polypeptides (Figure 3K). Further $\beta 1-3 \mathrm{GalNAc}$ activity was higher (3 fold) with respect to $\beta 1-4$ GalNAc-T activity in PA1 (Figure 10A). PA1 had much lower $\beta 1-3 \mathrm{Gal}-\mathrm{T}, \beta 1-4 \mathrm{Gal}-\mathrm{T}$, and neutral $\beta 1-3$ galactosidase activities (Figure 10B and 10C). Both SW626 and PA1 expressed very low level of $\alpha 2-3(\mathrm{O}) \mathrm{ST}$ (Figure 10C). It is apparent that the expression of $\beta 1-3 \mathrm{Gal}-\mathrm{T}, \beta 1-4 \mathrm{Gal}-\mathrm{T}$, neutral $\beta 1$-3galactosidase and $\alpha 2-3(\mathrm{O}) \mathrm{ST}$ may vary in ovarian cancer cells.

Prostate cancer cells: These cells expressed predominantly higher $\beta 1-3$ GalNAc-T activity as compared to other cancer cell lines with exception of DU4475 and MDA-MB-435S (Figure 10A). Neutral $\beta 1-3$ galactosidase activity was low in LNCaP. $\beta 1-3 \mathrm{Gal}-\mathrm{T}$ and $\beta 1-4 \mathrm{Gal}-\mathrm{T}$ activities were high in DU145. While $\alpha 2-3(\mathrm{O}) \mathrm{ST}$ activity was at high level in LNCaP (62.3) and PC3 (80.8) with respect to other cancer cell lines, it was found extremely low (0.7) in DU145 (Figure 10C). It seems that prostate cancer cells can be expected to contain a high level of $\beta 1$-3GalNAc-T, a2-3(O)ST and aGalNAc-T and most likely a low level of $\beta 1$-3galactosidase activity.

HL60, HepG2 and other cell lines: HepG2 as compared to HL60 expressed higher levels of GlcNAc: $\beta$ GalNAc-T ( 2 fold), neutral $\beta 1-3$ galactosidase ( 4 fold), $\beta 1-3 \mathrm{Gal}-\mathrm{T}$ ( $>3$ fold), $\alpha 2-3(\mathrm{O}) \mathrm{ST}$ ( $>3$ fold) and $\beta 1-4 \mathrm{Gal}-\mathrm{T}$ (2 fold) (Figure 10). HL60 had more heterogenous Ser/Thr containing polypeptides whereas the molecular size of these peptides was distinctively larger in HepG2 (Figure $3 \mathrm{M}$ and $3 \mathrm{~N}$ ). U87GB and RIF expressed 4.9 and 1.5 fold whereas EG7 and G261-OVA had 0.3 and 0.5 fold $\beta 1-4$ GalNAc-T as compared to $\beta 1-3$ GalNAc-T. Hepatic cancer cells HepG2 express high levels of neutral $\beta 1$-3galactosidase, $\beta 1-3 \mathrm{Gal}-\mathrm{T}, \beta 1-4 \mathrm{Gal}-\mathrm{T}$ and $\alpha 2-3(\mathrm{O}) \mathrm{ST}$ and high molecular size Ser/ Thr polypeptides. Lymphoma cells (EG7) and Glioma (GL261-OVA) express significantly very high activity of $\beta 1-3 \mathrm{GalNAc}-\mathrm{T}$ as compared to Glioblastoma (U87GB) and Fibrosarcoma (RIF).

The HPLC analysis of $\left[6-{ }^{3} \mathrm{H}\right]$ GalNAc-yl products arising from GlcNAc $\beta-\mathrm{O}-\mathrm{Bn}$ by the action of $\beta$ GalNAc-T from nine cancer cell lines and six tissue specimens showed that GlcNAc: $\beta 1-3$ GalNAc-T activities in prostate cancer cells LNcaP, PC3 and DU145, breast cancer cells DU4475 and MDA-MB-475S, ovarian cancer cells PA-1 and SW626 and pancreatic tumor specimens were present at higher level than $\beta 1-4 \mathrm{GalNAc}-\mathrm{T}$.

\section{Neutral $\beta 1-3$ galactosidase converting T-glycotope to $\mathrm{Tn}$ in cancer cells}

Several human cells express a $\beta$-galactosidase histochemically 


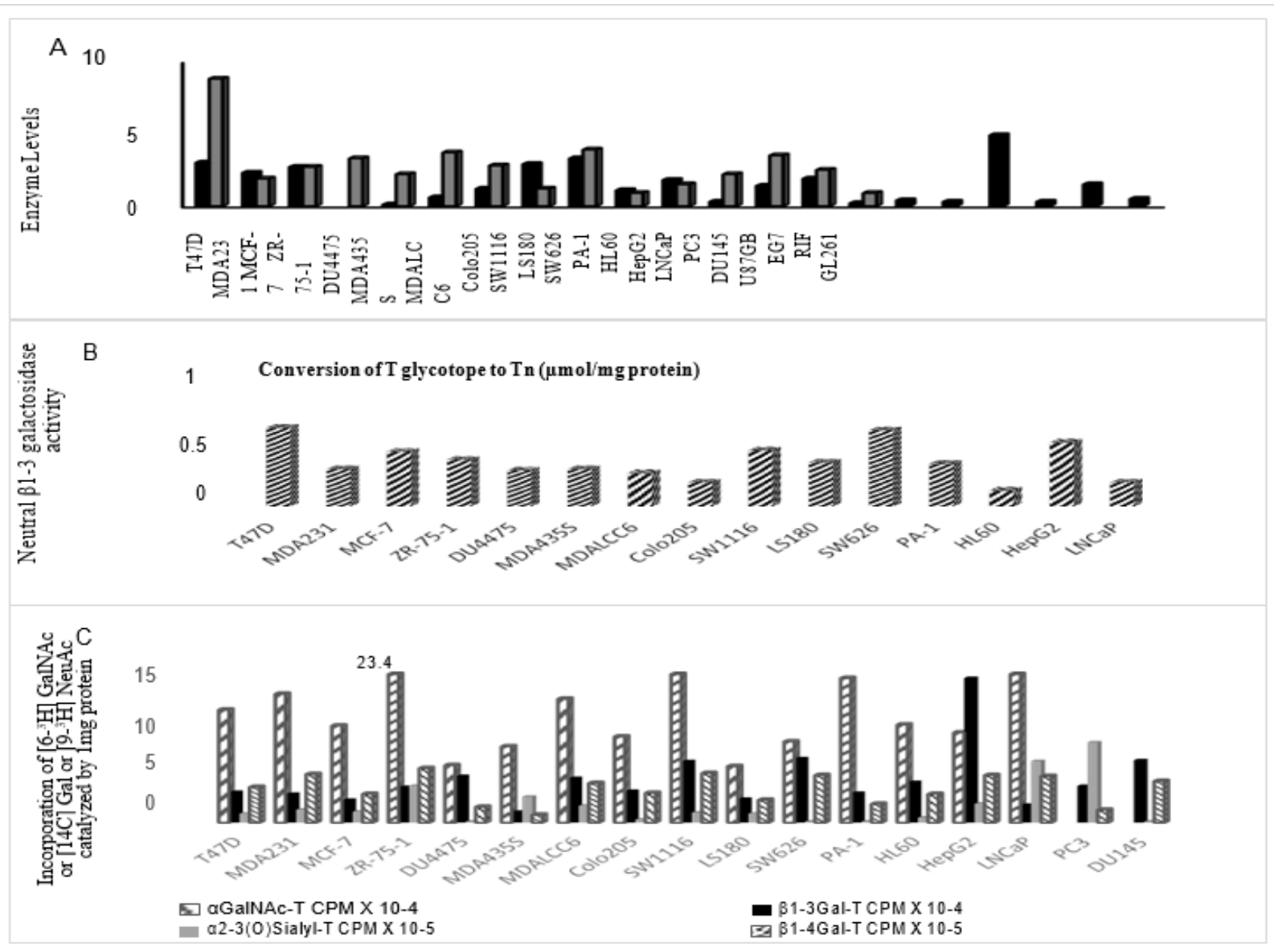

Figure 10: The levels of $\alpha$ and $\beta$ N-Acetylgalactosaminyltransferases and neutral $\beta 1-3 G$ alactosidase in human cancer cell lines.

Panel A: The fold of GlcNAc: $\beta 1-4$ GalNAc-T activity with respect to GlcNAc: $\beta 1-3 G a l N A c-T$ activity by measuring the activities with the acceptor GIcNAc $\beta-O-B n$ followed by WGA-agarose and VVL-agarose affinity cheomatography. The fold of endogenous acceptor polypeptide Ser/Thr: $\alpha$ GalNAc-T activity with respect to GIcNAc: $\beta 1-3 / 4$ activity by using GIcNAc $\beta 1-6$ (Galß1-3) GalNAca-O-Al as exogenous acceptor and followed by Biogel P2 column chromatographic separation and quantitation of Peak I and Peak II Franctions.

Panel B: For calculating the conversion of T-glycotope to Tn by neutral $\beta 1-3$ galactosidase activity in cancer cell lines, the percentage of PNA-agarose non-binding fractions were used.

Panel C: A comparison of the levels of aGalNAc-T ( ), aGalNAc: $\beta 1-3$ Gal-T ( ), $\alpha 2-3$ (O) ST (), GlcNAc: $\beta 1-4$ Gal-T ( ) in human cancer cell lines. For a meaningful understanding of the participating glycosyltransferases in O-glycans biosynthesis, the data obtained by using the same batch of cells on a2- 3 (O) ST, aGalNAc: $\beta 1-3 \mathrm{Gal}-\mathrm{T}$ and GIcNAc: $\beta 1-4 \mathrm{Gal}-\mathrm{T}$ were used from earlier publications.

detectable at $\mathrm{pH} 6$ upon senescence in culture. In skin samples from human donors of different age, there was an age-dependent increase in this marker in dermal fibroblasts and epidermal keratinocytes. Thus $\beta$-galactosidase is a bio marker that identifies senescent human cells in culture and in aging skin in vivo [38]. As senescent cells expressed 3-5-fold lysosomal $\beta$-galactosidase mRNA, there is a possibility of the $\mathrm{pH}$ optimum of lysosomal $\beta$-galactosidase being altered due to localization. Lysosomal $\beta$ - galactosidase cleaves $\beta$-linked terminal galactosyl residues from gangliosides, glycoproteins and glycosaminoglycans. Mutations in the $\beta$-galactosidase locus at chromosome 3 cause deficient or reduced enzyme activity [39].

The studies of $\beta$ galactosidases in senescent human cells [38], rat mammary gland [40], rat milk [40], bovine testes [41], bovine liver [42], human liver [43] and ovarian tumor tissue cells [44,45] indicate a lysosomal origin of $\beta$ galactosidase with an optimum $\mathrm{pH} 4.0$ and most of them are quite inactive at neutral $\mathrm{pH}$. The present study used the $\left[6-{ }^{3} \mathrm{H}\right]$ GalNAc containing product from the enzymatic transfer of $\left[6-{ }^{3} \mathrm{H}\right]$ GalNAc from UDP $\left[6-{ }^{3} \mathrm{H}\right]$ GalNAc $(0.2 \mu \mathrm{mol})$ to the GlcNAc moiety of the exogenous acceptor namely GlcNAc $\beta 1-6$ (Gal $\beta 1-3$ ) GalNAca-(O)- $\mathrm{Al}(3 \mu \mathrm{mol}$ in the reaction mixture) as the radioactive tracer to show the hydrolysis of $\beta 1-3$ linked Gal by a $\beta$ - galactosidase at neutral $\mathrm{pH}$. The cleavage of $\beta 1-3 \mathrm{Gal}$ was determined by the separation of binding and non-binding radioactive products on PNAagarose column as well as by the separation and quantitation of the two radioactive products using TLC. The study indicated that neutral $\beta$-galactosidase activity is significantly high in human cancer cell lines. There is also a distinctive variation in the level of this activity among the cancer cell lines. All breast cancer cells and HepG2 exhibited a high level of this activity whereas this activity varied among the other cell lines. HL60 (lymphoma) and LNCaP (prostate cancer) contained lower $\beta$-galactosidase activity. Apparently, the occurrence of $\beta 1-3$ galactosidase active at neutral $\mathrm{pH}$ for generating $\mathrm{Tn}$ epitope from $\mathrm{T}$ in cancer cell lines may have some biological significance. 


\section{Significance of $\beta$-galactosidase}

The biological significance of $\beta$-galactosidase became apparent when Dimri et al. [38] described the pH6 $\beta$ - galactosidase activity in human fibroblasts as a senescence-marker and designated it as SA$\beta$-Gal. Subsequently SA- $\beta$-Gal was identified in human umbilical vein [46], fibroblasts from venous ulcers [47] and ovarian epithelial cells [48]. Field et al. [48] demonstrated that the lysosomal $\beta$-Gal at $\mathrm{pH} 4.5$ showed $\sim 4$-fold and 25 -fold greater activity than at $\mathrm{pH} 6$ and 7 , respectively. Then it was shown that $\beta$-Gal activity decreased in a similar fashion with increase in $\mathrm{pH}$ both in liver homogenates of different age donors and in tumor cell lysates suggesting that pH6 $\beta$-Gal activity may not be an exclusive marker of senescence [50]. Long-term cultivation of Caco2-TC7 cells showed no specific association between cultivation time (cellular aging) and $\mathrm{pH} 6 \beta$-Gal activity as $\mathrm{pH} 4.5 \beta$-Gal exhibited the same pattern of increased activity [50]. The values for the $\beta$-Gal activity were reported as 115 and $185 \mathrm{nmol} / \mathrm{mg}$ protein at $\mathrm{pH} 4.5$ for HL60 and HepG2 and at pH6 32 and $47 \mathrm{nmol} / \mathrm{mg}$ protein, respectively. It is interesting to note that the present study found the neutral $\beta 1-3$ galactosidase activity as 120 and $480 \mathrm{nmol} / \mathrm{mg}$ protein for HL60 and HepG2, respectively. A recent study on human peritoneal mesothelial cells (HPMC) supports the theory that SA- $\beta-$ Gal detectable at $\mathrm{pH} 6$ is a reliable marker of senescence by showing that cytochemical and fluorescent methods of SA- $\beta$-Gal assessment may be informative for replicationdriven cell senescence in vitro and time-dependent organismal aging in vivo respectively [51]. Another recent study reports that elevated levels of HGF (Hepatocyte growth factor) and GRO-1 (Growth-regulated oncogene) in ovarian cancer malignant ascitic fluid induced senescence in HPMC as assessed by SA- $\beta-$ Gal and contribute to ovarian cancer progression [52]. A correlation between the activities of lysosomal $\beta$-galactosidase, senescence associated $\mathrm{pH} 6$ $\beta$-Galactosidase and the cancer cell neutral $\beta$ galactosidase identified in the present study remains to be seen.

Our earlier studies have well documented that $\alpha 2-3(\mathrm{O}) \mathrm{ST}$ activity is the most predominant sialyltransferase activity that accounts for $70-90 \%$ of the total sialylating activity in breast, colon and prostate cancer cell lines and also in tumor tissues of several cancers $[7,8]$. We found earlier that this enzyme (ST3 Gal II) has reversible sialylation activity by converting $5^{\prime} \mathrm{CMP}$ and also $5^{\prime} \mathrm{UMP}$ to $5^{\prime} \mathrm{CMP}$ - and 5'UMP-NeuAc by utilizing the donor NeuAca2-3Gal $\beta 1-3$ GalNAcaunits [53-55]. We also found highly significant level of the reversible sialylation activity in prostate cancer cells LNCaP and PC-3 [53]. We also determined that when CMPNeuAc $(5 \mathrm{mM})$ was incubated in 50mM Na Cacodylate pH6 containing 2\% Triton CF54 and 10mg $\mathrm{BSA} / \mathrm{ml}$ at $37^{\circ} \mathrm{C}$ for $4 \mathrm{~h}$, there was $30 \%$ breakdown of CMPNeuAc into CMP and NeuAc and thus 5'CMP becomes available for reverse sialylation [53].

Further it was shown that $5^{\prime} \mathrm{UMPNeuAc}$ is an inactive sialyl donor for the sialylation of glycans by $\alpha 2-3(\mathrm{O}) \mathrm{ST}, \alpha 2-3(\mathrm{~N}) \mathrm{ST}$ and $\alpha 2-6(\mathrm{~N})$ ST [53]. 5'UMP is apparently an efficient trap for sialic acid leading to depletion of glycan sialylation. Thus, the reversible sialylation activity in conjunction with sialidase and neutral $\beta 1-3$ galactosidase activity could generate Tn epitopes bearing polypeptides which apparently participate in cancer progression and metastasis. The extracellular sialylation in human plasma could then be responsible for the appearance of sialyl Tn epitope $[56,57]$.

\section{Significance of Type-I and Type-II LDN structures}

The biological significance of Type-I and Type-II LDN structures is evident from the expression of these structures on different glycoproteins, indicating their unique functions in vivo [15]. Most of Type-I LDN glycoproteins are localized to intra cellular organelles, particularly to the endoplasmic reticulum whereas Type-II LDN glycoproteins are extracellular [15]. Type-I LDN structure found in $\mathrm{O}$-mannose glycans on $\alpha$-dystroglycan is a key structure in lamininbinding glycans [58]. Sulfated Type-II LDN plays essential roles in the regulation of circulatory half-life of pituitary glycoprotein hormones [59]. We reported earlier that the B2 ion mass spectroscopy technique could be used to differentiate Type-I and Type-II LDN structures [60]. The present study showed the separation of the isomers GalNAc $\beta 1$ 3 GlcNAc $\beta-O-B n$, GalNAc $\beta 1-4$ GlcNAc $\beta-O-B n$ and GalNAc $\beta 1-$ $6 \mathrm{GlcNAc} \beta-\mathrm{O}-\mathrm{Bn}$ by HPLC. Further, the present study found that both Type-I and Type-II LDN structures bind to WFL-agarose whereas the weak and tight binding of Type-I and Type-II LDN products from the acceptor GlcNAc $\beta$-O-Bn to VVL- and WGA-agarose respectively can be used for measuring $\beta 1-3$ and $\beta 1-4$ GalNAc-T activities in cancer cell extracts. In this context, it is important to note that the evaluation of glycosyltransferase activities is essential due to the fact that the relation between gene expression and glycosyltransferase activities is commonly not uniform and often strikingly non-linear [61,62]. The affinity chromatography on VVL- and WGA-agarose could be further developed for the isolation and identification of Type-I and Type-II LDN terminal glycans and glycoproteins.

\section{Acknowledgement}

The study was supported by NIH Grants CA35329, HL103411 and Comprehensive Cancer Center Support Grant CA160561.

\section{References}

1. Drickamer K, Taylor ME. Evolving views of protein glycosylation. Trends Biochem. Sci. 1998: 23: 321-324.

2. McDermott KM, Crocker PR, Harris A, Burdick MD, Hinoda Y, Hayashi T, et al. Overexpression of MUC1 reconfigures the binding properties of tumor cells. Int. J. Cancer. 2001: 94: 783-791.

3. Singh AP, Moniaux N, Chauhan SC, Meza JL, Batra SL. Inhibition of MUC4 Expression Suppresses Pancreatic Tumor Cell Growth and Metastasis. Cancer Res. 2004: 64: 622-630.

4. Fuster MM, Esko JD. The Sweet and Sour of Cancer: Glycans as Nove Therapeutic Targets. Nat. Rev. Cancer. 2005: 5: 526-542.

5. Swanson BJ, McDermott KM, Singh PK, Eggers JP, Crocker PR, et al. MUC1 Is a Counter-Receptor for Myelin- Associated Glycoprotein (Siglec-4a) and Their Interaction Contributes to Adhesion in Pancreatic Cancer Perineural Invasion. Cancer Res. 2007: 67: 10222-10229.

6. Chandrasekaran EV, Chawda R, Rhodes JM, Locke RD, Piskorz CF Matta KL. The binding characteristics and utilization of Aleuria aurantia, Lens culinaris and few other lectins in the elucidation of fucosyltransferase activities resembling cloned $\mathrm{FT}$ VI and apparently unique to colon cancer cells. Carbohydr. Res. 2003: 338: 887-901.

7. Chandrasekaran EV, Xue J, Sriram Neelamegham S, Matta KL. The pattern of glycosyl- and sulfotransferase activities in cancer cell lines: a predictor of individual cancer-associated distinct carbohydrate structures for the structural identification of signature glycans. Carbohydr. Res. 2006: 341: 983-994.

8. Chandrasekaran EV, Marathe DD, Neelamegham S, Lau JY, Matta KL. A High-level Over-Expression of $\mathrm{N}$-and O- Glycan Glycosyltransferases in Pancreatic Tumors and Diabetic Neutrophils: An Unique Pathological Situation in Pancreatic Cancer and Diabetic Retinopathy. J. Glycobiol. 2019; 8: 138. 
9. Sakiyama T, Kabayama M, Tomita M, Nakamura J, Mukai H, Tomita $Y$, et al. Distribution of glycoproteins with $\beta-\mathrm{N}$-acetylgalactosaminylated $\mathrm{N}$-linked sugar chains among bovine tissues. Biochim. Biophys. Acta. 1998: 1380 268-274.

10. Furukawa K, Kitamura N, Sato T, Hiraizumi S. Differentiation-Associated Expression of $\mathrm{B}-\mathrm{N}$ - Acetylgalactosaminylated N-Linked Oligosaccharides in Mammary Epithelial Cells. Adv. Exp. Med. Biol. 2001: 491: 313-323.

11. Hirano K, Matsuda A, Shirai T, Furukawa K. Expression of LacdiNAc Groups on N-Glycans among Human Tumors Is Complex. BioMed Res. Intl. 2014.

12. Kitamura N, Guo S, Sato T, Hiraizumi S, Taka J, Ikekita M, et al. Prognostic significance of reduced expression of $\beta^{\prime} \mathrm{N}$-acetylgalactosaminylated $\mathrm{N}$-linked oligosaccharides in human breast cancer. Int. J. Cancer. 2003; 105: 533-541.

13. Yoneyama T, Tobisawa $\mathrm{Y}$, Kaneko T, Kaya T, Hatakeyama S, Mori K, et al. Clinical Significance of the LacdiNAc-glycosylated Prostate-Specific Antigen Assay for Prostate Cancer Detection. Cancer Science. 2019: 110: 2573-2589.

14. Ohkura T, Seko A, Hara-Kuge S, Yamashita K. Occurrence of Secretory Glycoprotein-Specific GalNAcß1-4 GlcNAc Sequence in N-Glycans in MDCK Cells. The Journal of Biochemistry. 2002; 132: 891-901.

15. Nakane T, Angata $K$, Sato T, Kaji H, Narimatsu $H$. Identification of mammalian glycoproteins with type-I LacdiNAc structures synthesized by the glycosyltransferase 33 GALNT2. J. Biol Chem. 2019: 294: 7433-7444.

16. Alfalah M, Jacob R, Preuss U, Zimmer K-P, Naim H, Y. Naim H. O-linked glycans mediate apical sorting of human intestinal sucrase-isomaltase through association with lipid rafts. Curr. Biol. 1999: 9: 593-596.

17. Altschuler Y, Kinlough CL, Poland PA, Bruns JB, Apodaca G, Weisz OA, et al. Clathrin-mediated Endocytosis of MUC1 Is Modulated by Its Glycosylation State. Mol. Biol. Cell. 2000: 11: 819-831.

18. Breuza L, Garcia M, Delgrossia M-H, Bivica AL. Role of the Membrane Proximal O-glycosylation Site in Sorting of the Human Receptor for Neurotrophins to the Apical Membrane of MDCK Cells. Exp. Cell. Res. 2002 273: 178-186.

19. Zheng X, Sadler JE. Mucin-like Domain of Enteropeptidase Directs Apical Targeting in Madin-Darby Canine Kidney Cells. J. Biol. Chem. 2002: 277 6858-6863.

20. McGuire EJ, Roseman S. Enzymatic Synthesis of the Protein-Hexosamine Linkage in Sheep Submaxillary Mucin. J. Biol. Chem. 1967: 242: 3745-3755.

21. Wandall HH, Irazoqui F, Tarp MA, Bennett EP, Mandel U, Takeuchi H, et al The lectin domains of polypeptide GalNAc-transferases exhibit carbohydratebinding specificity for GalNAc: lectin binding to GalNAc-glycopeptide substrates is required for high density GalNAc-O-glycosylation. Glycobiol. 2007: 17 : 374-387.

22. Springer GF. T and Tn, general carcinoma autoantigens. Science. 1984; 224 1198-1206.

23. Itzkowitz SH, Yuan M, Montgomery CK, Kjeldsen T, Takahashi HK, Bigbee WL, et al. Expression of Tn, Sialosyl- Tn, and T Antigens in Human Colon Cancer. Cancer Res. 1989; 49: 197-204.

24. Kumar SR, Sauter ER, Quinn TP, Deutscher SL. Thomsen-Friedenreich and Tn Antigens in Nipple Fluid: Carbohydrate Biomarkers for Breast Cancer Detection. Clin. Cancer Res. 2005; 11: 6868-6871.

25. Brooks SA, Hall DMS. Investigations into the potential role of aberrant $\mathrm{N}$-acetylgalactosamine glycans in tumour cell interactions with basement membrane components. Clin. Exptl. Metastasis. 2002; 19: 487-493.

26. Dall'Olio F, Malagolini N, Trinchera M, Chiricolo M. Mechanisms of CancerAssociated Glycosylation Changes. Front. Biosci. (Landmark Ed). 2012; 17 670-699.

27. Chandrasekaran EV, Jain RK, Vig R, Matta KL. The enzymatic sulfation of glycoprotein carbohydrate units: blood group T-hapten specific and two other distinct Gal: 3-O-sulfotransferases as evident from specificities and kinetics and the influence of sulfate and fucose residues occurring in the carbohydrate chain on C-3 sulfation of terminal Gal. Glycobiol. 1997; 7: 753-767.

28. Chandrasekaran EV, Jain RK, Rhodes JM, Chawda R, Piskorz C, Matta KL.
Characterization of distinct Gal: 3-O-sulfotransferase activities in human tumor epithelial cell lines and of calf lymph node GIcNAc: 6-O- sulfotransferase activity. Glycoconj. J. 1999; 16: 523-536.

29. Chandrasekaran EV, Xue J, Piskorz C, Locke RD, Tóth K, Slocum HK, et al. Potential tumor markers for human gastric cancer: an elevation of glycan: sulfotransferases and a concomitant loss of $\alpha 1,2$-fucosyltransferase activities. J. Cancer Res. Clin. Oncol. 2007; 133: 599-611.

30. Chandrasekaran EV, Chawda R, Locke RD, Piskorz CF, Matta KL. Biosynthesis of the carbohydrate antigenic determinants, Globo $\mathrm{H}$, blood group $\mathrm{H}$, and Lewis b: a role for prostate cancer cell a1,2-L-fucosyltransferase. Glycobiol. 2002; 12: 153-162.

31. Chandrasekaran EV, Xue J, Xia J, Chawda R, Piskorz C, Locke RD, et al. Analysis of the Specificity of Sialyltransferases toward Mucin Core 2, Globo, and Related Structures. Identification of the Sialylation Sequence and the Effects of Sulfate, Fucose, Methyl, and Fluoro Substituents of the Carbohydrate Chain in the Biosynthesis of Selectin and Siglec Ligands, and Novel Sialylation by Cloned a2,3(O)Sialyltransferase. Biochemistry. 2005; 44: 15619-15635.

32. Chandrasekaran EV, Xue J, Xia J, Khaja SD, Piskorz CF, Locke RD, et al. Novel interactions of complex carbohydrates with peanut (PNA), Ricinus communis (RCA-I), Sambucus nigra (SNA-I) and wheat germ (WGA) agglutinins as revealed by the binding specificities of these lectins towards mucin core-2 O-linked and N-linked glycans and related structures. Glycoconj. J. 2016; 33: 819-836.

33. Chen Y, Jain RK, Chandrasekaran EV, Matta K L. Use of sialylated or sulfated derivatives and acrylamide copolymers of Gal $\beta 1,3 \mathrm{GalNAc \alpha -}$ and GalNAca- to determine the specificities of blood group $\mathrm{T}$ - and $\mathrm{Tn}$-specific lectins and the copolymers to measure anti-T and anti-Tn antibody levels in cancer patients. Glycoconj. J. 1995; 12: 55-62.

34. Daenzer JMI, Sanders RD, Hang D, Fridovich-Keil JL. UDP-Galactose 4'-Epimerase Activities toward UDP-Gal and UDP-GalNAc Play Different Roles in the Development of Drosophila melanogaster. 2012. https://doi. org/10, 1371/journal.pgen.1002721

35. Esko JD, Selleck SB. Order Out of Chaos: Assembly of Ligand Binding Sites in Heparan Sulfate. Annual Review of Biochemistry. 2002; 71: 435-471.

36. Varki A. Nothing in Glycobiology Makes Sense, except in the Light of Evolution. Cell. 2006; 126: 841-845.

37. Dalziel M, Crispin M, Scanlan CN, Zitzmann N, Dwek RA. Emerging Principles for the Therapeutic Exploitation of Glycosylation. Science. 2014; 343: 1235681

38. Dimri GP, Lee X, Basile G, Acosta M, Scott G, Roskelley C, et al. A biomarker that identifies senescent human cells in culture and in aging skin in vivo. Proc Natl. Aca. Sci. 1995; 92: 9363-9367.

39. Shows TB, Scrafford-Wolff LR, Brown JA, Meisler MH. GM1-gangliosidosis: Chromosome 3 assignment of the $\beta$ - galactosidase- $A$ gene ( $\beta$ GALA) Somatic Cell Genetics. 1979; 5: 147-158.

40. Chao-Hen K, Wells WW. $\beta$-galactosidase from rat mammary gland: Its purification, properties and role in the biosynthesis od 6 $\beta-O-D$ galactopyranosyl myo-inositol. J. Biol. Chem. 1978; 253: 3350-3356.

41. Distler JJ, Jourdian GW. The Purification and Properties of $\beta$-Galactosidase from Bovine Testes. J. Biol. Chem. 1973; 248: 6772-6780

42. DiCioccio RA, Barlow JJ, Matta KL. Purification of a $\beta$-d-galactosidase from bovine liver by affinity chromatography. Carbohydr. Res. 1984; 127: 109-120.

43. Meisler M. $\beta$-galactosidase from human liver. Methods Enzymol. 1972; 28 820-824.

44. Chatterjee SK, Bhattacharya M, Barlow JJ. Glycosyltransferase and Glycosidase Activities in Ovarian Cancer Patients. Cancer Res. 1979; 39: 1943-1951.

45. Asanuma D, Sakabe M, Kamiya M, Yamamoto K, Hiratake J, Ogawa M, et al. Sensitive $\beta$-galactosidase-targeting fluorescence probe for visualizing small peritonial metastatic tumours in vivo. Nat. Commun. 2015; 6: 6463/DOI: 10 1038-7463. 
46. Van der Loo B, Fenton MJ, Erusalimsky JD. Cytochemical Detection of a Senescence-Associated $\beta$-Galactosidase in Endothelial and Smooth Muscle Cells from Human and Rabbit Blood Vessels. Exp. Cell Res. 1998; 241: 309315 .

47. Mendez MV, Stanley A, Park HY, Shon K, Phillips T, Menzoian JO. Fibroblasts Cultured from Venous Ulcers Display Cellular Characteristics of Senescence. J. Vasc. Surg. 1998; 28: 876-883.

48. Litaker JR, Pan J, Cheung Y, Zhang DK, Liu Y, Wong SC, et al. Expression profile of senescence-associated beta- galactosidase and activation of telomerase in human ovarian surface epithelial cells undergoing immortalization. Int. J. Oncol. 1998; 13: 951-957.

49. Field M, Papac, D, Jones A. The Use of High Performance Anion-Exchange Chromatography and Matrix-Assisted Laser Desorption Mass Spectrometry to Monitor and Identify Oligosaccharide Degradation. Anal. Biochem. 1996; 239: 92-98.

50. Krishna DR, Sperker B, Fritz P, Klotz U. Does pH 6 -galactosidase activity indicate cell senescence? Mech. Ageing Dev. 1999; 109: 113-123.

51. Sosińska P, Mikuła-Pietrasik J, Ryżek M, Naumowicz E, Książek K Specificity of cytochemical and fluorescence methods of senescenceassociated $\beta$-galactosidase detection for ageing driven by replication and time. Biogerontology. 2014; 15: 407-413.

52. Mikuła-Pietrasik J, Uruski P, Matuszkiewicz K, Szubert S, Moszyński R, Szpurek D, et al. Ovarian Cancer-Derived Ascitic Fluids Induce a Senescence-Dependent Pro-Cancerogenic Phenotype in Normal Peritoneal Mesothelial Cells. Cell Oncol. 2016; 39: 473-481.

53. Chandrasekaran EV, Xue J, Xia J, Locke RD, Matta KL, Neelamegham S. Reversible Sialylation: Synthesis of Cytidine 5'-Monophospho-Nacetylneuraminic Acid from Cytidine 5'-Monophosphate with a2,3-Sialyl O-Glycan-, Glycolipid-, and Macromolecule-Based Donors Yields Diverse Sialylated Products. Biochemistry. 2008; 47: 320-330.

54. Chandrasekaran EV, Xue J, Xia J, Locke RD, Patil SA, Neelamegham S, et al. Mammalian sialyltransferase ST3Gal-II: Its exchange sialylation catalytic properties allow labeling of sialyl residues in mucin type sialylated glycoproteins and specific gangliosides. Biochemistry. 2011; 50: 9475-9487.

55. Chandrasekaran EV, Xue J, Xia J, Locke RD, Patil SA, Neelamegham S, et al. Characterization of cancer associated mucin type O-glycans using the exchange sialylation properties of mammalian sialyltransferase ST3Gal- II. J. Proteomic. Res. 2012; 11: 2609-2618.

56. Lee-Sundlov MM, Ashline DJ, Hanneman AJ, Grozovsky R, Reinhold VN, Hoffmeister KM, et al. Circulating blood and platelets supply glycosyltransferases that enable extrinsic extracellular glycosylation. Glycobiology. 2017; 27: 188-198.

57. Zhang Z, Wuhrer M, Holst S. Serum sialylation changes in cancer. Glycoconj. J. $2017 ; 35: 139-160$

58. Yoshida-Moriguchi T, Yu L, Stalnaker SH, Davis S, Kunz S, Madson M, et al. O-Mannosyl Phosphorylation of Alpha-Dystroglycan Is Required for Laminin Binding. Science. 2010; 327: 88-92.

59. Fiete D, Srivastava V, Hindsgaul O, Baenziger JU. A hepatic reticuloendothelial cell receptor specific for SO4- 4GalNAc beta 1,4GlcNAc beta 1,2Man alpha that mediates rapid clearance of lutropin. Cell. 1991; 67: 1103-1110.

60. Xue J, Laine RA, Matta KL. Enhancing MSn mass spectrometry strategy for carbohydrate analysis: A b2 ion spectral library. J. Proteomics. 2015; 112 : 224-249.

61. Comelli EM, Head SR, Gilmartin T, Whisenant T, Haslam SM, North SJ, et al. A focused microarray approach to functional glycomics: Transcriptional regulation of the glycome. Glycobiology. 2006; 16: 117-131.

62. Nairn AV, Aoki K, dela Rosa M, Porterfield M, Lim JM, Kulik M, et al. Regulation of glycan structures in murine embryonic stem cells: combined transcript profiling of glycan-related genes and glycan structural analysis. J. Biol. Chem. 2012; 287: 37835-37856. 